\title{
Ontogenetic changes in mouth morphology triggers conflicting hypotheses of relationships in characid fishes (Ostariophysi: Characiformes)
}

\author{
Alice Hirschmann ${ }^{1}$, Nelson J. R. Fagundes ${ }^{2}$ and Luiz R. Malabarba ${ }^{3}$
}

Bryconamericus lethostigmus is the type-species of the monotypic genus Odontostoechus, diagnosed in part based on the presence of a unique tooth series in the premaxilla. Recently a new proposal of classification of the Stevardiinae placed Odontostoechus as a junior synonym of a monophyletic genus Bryconamericus sensu stricto, a genus characterized by the presence of two tooth series. Bryconamericus lethostigmus is redescribed herein and the single tooth series in the premaxilla is demonstrated to originate from merging of the external tooth row with the inner row during ontogeny refuting primary hypothesis of homology between the mouth morphology of B. lethostigmus and the genera Bryconacidnus, Ceratobranchia, Monotocheirodon, Othonocheirodus, Rhinopetitia and Rhinobrycon. A phylogeographic analysis indicated that the pattern described for the sympatric species Diapoma itaimbe is not mirrored by B. lethostigmus. The results also do not support the hypothesis of a new species in the rio Araranguá drainage.

Keywords: Atlantic Forest, Cyanocharax itaimbe, Phylogeography, Tooth series, Tramandai-Mampituba ecoregion.

Bryconamericus lethostigmus é a espécie tipo do gênero monotípico Odontostoechus, diagnosticado em parte pela presença de uma única série de dentes na pré-maxila. Recentemente uma nova proposta de classificação de Stevardiinae considerou Odontostoechus como sinônimo júnior do gênero monofilético Bryconamericus sensu stricto caracterizado pela presença de duas séries de dentes. Bryconamericus lethostigmus é redescrito e demonstra-se que a única série de dentes no premaxilar se origina pela junção da série externa de dentes com a série interna durante a ontogenia, refutando a hipótese de homologia primária entre a morfologia da boca de B. lethostigmus e os gêneros Bryconacidnus, Ceratobranchia, Monotocheirodon, Othonocheirodus, Rhinopetitia e Rhinobrycon. A análise filogeográfica indica que o padrão descrito para a espécie simpátrica Diapoma itaimbe não se repete em B. lethostigmus. Os resultados também não suportam a hipótese de uma nova espécie para a bacia do rio Araranguá.

Palavras-chave: Cyanocharax itaimbe, Dentição, Ecoregião Tramandaí-Mampituba, Filogeografia, Mata Atlântica.

\section{Introduction}

Bryconamericus lethostigmus (Gomes) was described as the type-species of the monotypic characid genus Odontostoechus Gomes, originally assigned to the subfamily Cheirodontinae due to the presence of a single tooth series in the premaxilla. Gomes (1947) proposed the genus Odontostoechus as related to Distoechus Gomes (= Deuterodon Eigenmann), Othonocheirodus Myers and Monotocheirodon Eigenmann \& Pearson based on the structure of the mouth, and, in the case of the last two genera, by the presence of two rows of gill rakers on the lower ramus of the branchial arches. Indeed, Böhlke (1954) suggested a new
Cheirodontinae tribe, the Monotocheirodontini, composed by Odontostoechus lethostigmus, Othonocheirodus and Monotocheirodon, based on similarities of the mouth, while Géry (1977) placed Odontostoechus as a junior synonym of Othonocheirodus. However, Malabarba (1998) considered Odontostoechus as a possibly valid genus encompassing several Bryconamericus-like species. This author suggested that the single tooth series in Odontostoechus originates during ontogeny where the premaxilla forms from the merging of the two tooth series, and therefore, that the presence a single tooth series is not homologous in regard to other Cheirodontinae species, placing the genus as incertae sedis in Characidae.

${ }^{1}$ Programa de Pós-Graduação em Biologia Animal, Universidade Federal do Rio Grande do Sul, 91501-970 Porto Alegre, RS, Brazil. alicehirschmann@gmail.com (corresponding author)

${ }^{2}$ Departamento de Genética, Universidade Federal do Rio Grande do Sul, 91501-970 Porto Alegre, RS, Brazil, Email: nelson.fagundes@ufrgs.br ${ }_{3}^{3}$ Departamento de Zoologia, Universidade Federal do Rio Grande do Sul, 91501-970 Porto Alegre, RS, Brazil. malabarb@ufrgs.br 
Malabarba, Weitzman (2003) provided a better resolution for the phylogenetic relationships among the species described by Gomes by diagnosing a monophyletic group of characid fishes, referred therein as Clade A that included Odontostoechus lethostigmus. This hypothesis was corroborated by molecular (Javonillo et al., 2010; Oliveira et al., 2011) and morphological (Mirande, 2010) phylogenies that support the monophyly of Clade A. Mirande (2010) named that clade Stevardiinae, which was further corroborated by Baicere-Silva et al. (2011), who found that the spermiogenesis process in Odontostoechus lethostigmus is homologous with regard to other Stevardiinae.

Among stevardiines, Odontostoechus has been hypothesized be more closely related to Creagrutus Günther, Nantis Mirande, Aguilera \& Azpelicueta, and Piabina Reinhardt based on an implied weighting parsimony analysis including several characters (Mirande, 2010). However, Menezes et al. (2013) proposed, like Böhlke (1954), that Odontostoechus was closely related to Bryconacidnus Myers, Ceratobranchia Eigenmann, Monotocheirodon, Othonocheirodus and Rhinopetitia Géry or to these genera plus Rhinobrycon Myers, based on similarities in the mouth shape (Netto-Ferreira et al., 2014). On the other hand, the molecular phylogenies of Javonillo et al. (2010) and Oliveira et al. (2011) grouped Odontostoechus with Bryconamericus and Hypobrycon Malabarba \& Malabarba, and more recently, Thomaz et al. (2015a) proposed a new classification for Stevardiinae tribes and genera, placing Odontostoechus as a junior synonym of a monophyletic genus Bryconamericus sensu stricto.

Bryconamericus lethostigmus is a specialized riverine fish from South Brazilian coastal drainages, originally described from the rio Maquiné (rio Tramandaí drainage). Morphologically similar populations have been found on the northern neighbour drainages of rio Três Forquilhas (also from rio Tramandaí drainage), rio Mampituba and rio Araranguá.
Malabarba (1998: 232) suggested that the population from the rio Araranguá may represent a new species. These river drainages comprise the Tramandai-Mampituba Freshwater Ecoregion (unit 335 - Abell et al., 2008; Fig. 1), an area of high endemism of fish species because of the congruent distributional pattern among several species that are solely found among these three drainages (Malabarba, Isaia, 1992). Recently, Hirschmann et al. (2015) showed that Diapoma itaimbe (Malabarba \& Weitzman, 2003), another member of Stevardiinae, has a very strong genetic structure among these drainages, and that the rio Araranguá population is the most distinct among them. Bryconamericus lethostigmus and $D$. itaimbe are sympatric and share the same habitats with clear and cold waters over rocky substrates, leading to the hypothesis that $B$. lethostigmus may also have strong population structure among these drainages.

The alternative hypotheses of phylogenetic relationships of Bryconamericus lethostigmus and the possibility that one of its populations actually represents a new species demonstrate the need to redescribe this species and delimit its range of morphological and genetic variation. In thisstudy, weredescribe Bryconamericus lethostigmus based on the examination of several populations including that of rio Maquiné from where the species was originally described (Gomes, 1947). Next, we describe and analyse the mouth shape and the origin of a single series of teeth in the premaxilla in B. lethostigmus, a species of a group characterized by the presence of two tooth series, and discuss its phylogenetic implications and possible homologies with other stevardiines. Finally, we analyse the genetic variation found in the populations of $B$. lethostigmus from the Tramandai-Mampituba ecoregion (Abell et al., 2008) to test if this species displays the same phylogeographic structure observed for D. itaimbe (Hirschmann et al., 2015), and if the rio Araranguá population represents a different species (Malabarba, 1998: 232).

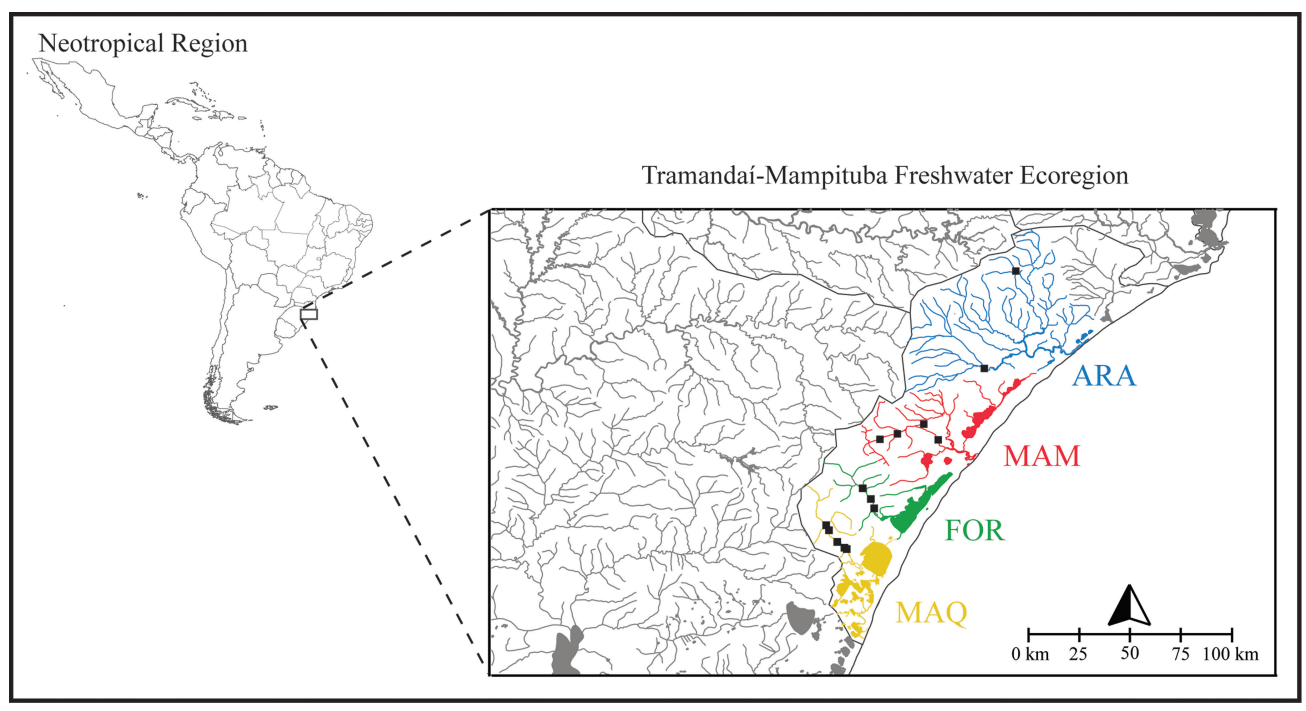

Fig. 1. Geographical distribution of Bryconamericus lethostigmus in northern Rio Grande do Sul and southern Santa Catarina States, Tramandai-Mampituba Freshwater Ecoregion (Abell et al., 2008). Squares represent localities of collection of $B$. lethostigmus for DNA analysis. Each mark may represent more than one lot. 


\section{Material and Methods}

Morphological analyses. Measurements and counts were taken following Fink, Weitzman (1974), except for analfin base length measured between the origin of the first and last anal-fin rays; dorsal-fin base length measured between the origin of the first and last dorsal-fin rays; maxillary length measured from the contact with the premaxilla to its posterior tip; premaxillary length measured from the anterior tip to the contact with the maxilla; mouth width measured in the largest mouth gap. Measured specimens come from all four river drainages inhabited by this species (rio Araranguá - ARA; rio Mampituba - MAM; rio Três Forquilhas - FOR; and rio Maquiné - MAQ). Counts of vertebrae, teeth and procurrent caudal-fin rays were taken from cleared and stained specimens (c\&s) prepared according to Taylor, Van Dyke (1985). We included the four vertebrae of the Weberian apparatus in vertebral counts, and counted the terminal centrum as a single element. We took measurements point to point with a calliper on the left side of specimens. We recorded all measurements as percents of standard length (SL) except for subunits of the head, which we recorded as percents of head length (HL). Sex of adult specimens of Bryconamericus was determined by the presence (males) or absence (females) of bony hooks in fin rays. Differences in measurements and counts among the four populations were tested with the Kruskal-Wallis test and post-test multiple comparisons using pgirmess package (Giraudoux, 2013) in R (R Development Core Team, 2013). We used the software Past (Hammer et al., 2001) to perform Principal Component Analysis (PCA) with morphometric data. All measurements were log-transformed to compare morphometric variations between populations. Specimens examined belong to the following institutions: MCP (Museu de Ciências e Tecnologia, Pontifícia Universidade Católica do Rio Grande do Sul, Porto Alegre, Brazil), UFRGS (Departamento de Zoologia, Universidade Federal do Rio Grande do Sul, Porto Alegre, Brazil), UMMZ (University of Michigan, Museum of Zoology, Ann Arbor, USA) and USNM (National Museum of Natural History, Smithsonian Institution, Washington D.C., USA).

Molecular analyses. We used tissue samples from 45 specimens of Bryconamericus lethostigmus collected throughout its distribution and maintained in 96\% ethanol in the fish collection at Departmento de Zoologia, Universidade Federal do Rio Grande do Sul (UFRGS). Tissue samples are identified as "TEC" in the list of examined material and include individuals from all four river systems in the range of this species (rio Araranguá - ARA; rio Mampituba MAM; rio Três Forquilhas - FOR; and rio Maquiné - MAQ).

DNA extraction followed a modified salt precipitation protocol (Medrano et al., 1990). For each sample we used PCR to amplify two mitochondrial genes: cytochrome oxidase subunit I $(C O I)$ and the NADH dehydrogenase 2 (ND2) and three nuclear genes: SH3 and PX domain- containing 3-like protein ( $S H 3 P X 3)$, S7 ribosomal protein intron 2 (S72) (Cooke, Beheregaray, 2007) and myosin heavy chain 6 gene (Myh6) (Li et al., 2007). PCRs were carried out in $20 \mu \mathrm{l}$ reactions containing $10-50 \mathrm{ng}$ DNA, $0,2 \mu \mathrm{M}$ of each primer, $0,2 \mathrm{mM}$ of each dNTP, $1 \times$ Buffer, $1,5 \mu \mathrm{M} \mathrm{MgCl}_{2}$ and 1U Platinum Taq DNA polymerase (Invitrogen, São Paulo, BR). PCR conditions and primers are presented in (Appendix S1 - Available only as online supplementary file accessed with the online version of the article at http://www. scielo.br/ni). PCR products were checked by electrophoresis in agarose gel, purified using EXOSAP (Exonuclease I and Shrimp Alkaline Phosphatase GE Healthcare ${ }^{\circledR}$, Piscataway, USA) and sequenced in both directions in Macrogen Inc, Seoul, South Korea.

Forward and reverse reads were assembled and visualized using Geneious 5.6.7 (Drummond et al., 2012). The consensus sequences were automatically aligned using the software CLUSTALW (Thompson et al., 1994) in BIOEDIT 7.1.3.0 (Hall, 1999) with default parameters. The mitochondrial coding genes COI and ND2 were concatenated for all analyses. Basic descriptive statistics, such as nucleotide $(\pi)$ and haplotype diversity (hd) as well as neutrality tests were calculated in the software DNASPv5 (Librado, Rozas, 2009). Genetic distances among populations were calculated using the Kimura 2-parameter (K2P) substitution model (Kimura, 1980) using MEGA 6 (Tamura et al., 2013). Genetic structure among populations was quantified through the Analysis of Molecular Variance (AMOVA) carried out in the program ARLEQUIN 3.5 (Excoffier, Lischer, 2010). For this analysis, we considered individuals sampled in each river drainage as coming from different populations.

Evolutionary relationship among haplotypes were estimated based on the median-joining method (MJN) (Bandelt et al., 1999) using the program NETWORK 4.1.0.8 (www.fluxus-engineering.com). Estimates the mtDNA coalescence time and the historical effective population size $(\mathrm{Ne})$ using the BEAST 1.8.2 package (Drummond et al., 2012). The mtDNA data set was analysed assuming an evolutionary rate of $0.01 / \mathrm{site} / \mathrm{Myr}$ (Bermingham et al., 1997; Reeves, Bermingham, 2006; Ornelas-García et al., 2008) and a strict clock model, which is a generally well justified for analysis within a species or among a few closely related species (Li, Drummond, 2011). To compare the evolutionary history of $B$. lethostigmus to that of a sympatric species, we estimated coalescence times and population sizes for $D$. itaimbe based on sequences obtained from GenBank (KP399679 to KP399733; KP406648 to KP406702; Hirschmann et al., 2015). Based on the Bayesian Information Criterion in PartitionFinder (Lanfear et al., 2012) we assumed the HKY+I substitution model for COI and ND2. Ten million Markov chain Monte Carlo (MCMC) steps were performed for coalescence time estimation and samples were collected every 1,000 steps. The efficiency of the chain was assessed in Tracer 1.5 (Rambaut, Drummond, 2009) with 10\% burn-in. 
Results

\section{Bryconamericus lethostigmus (Gomes, 1947)}

Figs. 2-6

Odontostoechus lethostigmus Gomes, 1947: 07-12 [original description; holotype: UMMZ 143272; paratypes: CAS-SU 40188(1) and UMMZ143271 (originally 12, now 11; 1 specimen posteriorly transferred to USNM 143847); fig. 1 (head and dentition); plate I, fig. 1 (photo of the holotype); type-locality: rio Maquiné, tributary to Lagoa dos Quadros, Conceição do Arroio County, currently Maquiné County, Rio Grande do Sul, Brazil]. - Böhlke, 1954: 25 [listed; Odontostoechus lethostigmus as member of the tribe Monotocheirodonini]. Malabarba, 1998: 204; 231-232 [Odontostoechus as a valid genus separate from Othonocheirodus and incertae sedis in Characidae; brief description of the tooth series in the premaxilla; presence of a single tooth series in the premaxilla in Odontostoechus hypothesized as non homologous to that of the species of Cheirodontinae]. - Marques et al., 2002: 28 [categorized as Vulnerable - VU in Rio Grande do Sul State, Brazil, according to IUCN criteria]. Reis et al., 2003: 127 [conservation status, distribution, menaces, categorized as
Vulnerable - VU in Rio Grande do Sul state, Brazil, according to IUCN criteria]. - Charcansky, 2006: 101-102 [tooth morphology and histology], fig. 32 [tooth morphology], fig. 33 [tooth histology]. - Javonillo et al., 2010: 505 [phylogenetic relationships]. - Baicere-Silva et al., 2011: 379380,383 [description of spermiogenesis and ultrastructure of the spermatozoa], fig. 12 [scanning electronic images of the ultrastructure of the spermatozoa]. - Oliveira et al., 2011 [relationships], 23 [more closely related to Hypobrycon and Bryconamericus exodon]. - Malabarba et al., 2013: 48 [colour photo, diagnosis, biology, distribution and habitat]. Menezes et al., 2013: 143 [possibly related to Ceratobranchia cf. delotaenia, Bryconacidnus ellisi, Rhinopetitia cf. myersi, Rhinopetitia sp., Othonocheirodus sp. and Monotocheirodon). - Netto-Ferreira et al., 2014: 1545-1548 [proposal of close relationships among the genera Rhinopetitia, Bryconacidnus, Ceratobranchia, Monotocheirodon, Odontostoechus, Othonocheirodus and Rhinobrycon].

Othonocheirodus lethostigmus. Géry, 1977: 559 [Odontostoechus as a junior synonym of Othonocheirodus].

Bryconamericus lethostigmus. Thomaz et al., 2015a: additional file 5 [Odontostoechus as a junior synonym of Bryconamericus sensu stricto]. - Bertaco et al., 2016: 412, table 1 [species list from Rio Grande do Sul State].

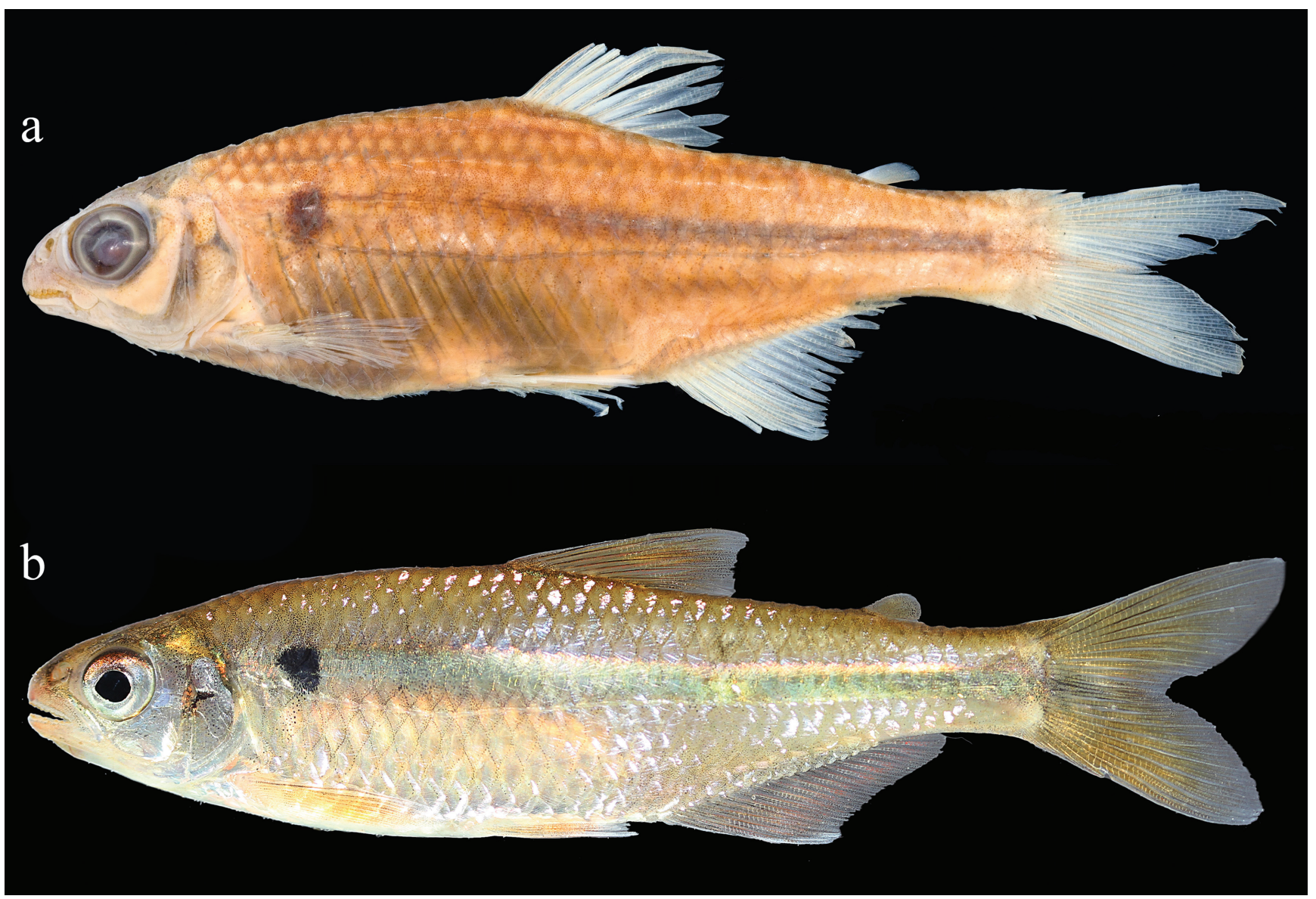

Fig. 2. Bryconamericus lethostigmus. a. holotype, $48.68 \mathrm{~mm}$ SL (UMMZ 143272); b. color in life in a fresh collected specimen, rio Três Forquilhas basin, Itati, Rio Grande do Sul, Brazil, UFRGS 16500. 
Diagnosis. Bryconamericus lethostigmus is distinct from all other species of the genus by the following autapomorphy: presence of two rows of teeth in the premaxilla in small specimens (up to about $30 \mathrm{~mm} \mathrm{SL}$ ) progressively merging in one tooth row in the premaxilla in large specimens (more than about $40 \mathrm{~mm} \mathrm{SL}$ ) (vs. two tooth rows in the premaxilla regardless of body size). This species is distinct from all congeners by the atrophied upper lip in large specimens, leaving the premaxillary teeth exposed. This character is associated with its common name, "smiling tetra".
Description. Morphometric data is summarized in Tab. 1. Body moderately elongate and compressed. Dorsal profile slightly convex from head until dorsal-fin origin, nearly straight from posterior dorsal-fin base to adipose fin and slightly concave from adipose-fin base to caudal-fin origin. Ventral body profile slightly convex from head to anal-fin origin, straight along anal-fin base and slightly concave from posterior anal-fin base to caudal-fin origin. Greatest depth at dorsal-fin origin or somewhat anterior. Caudal peduncle slightly longer than deep. Dorsal and ventral profiles of caudal peduncle slightly concave.

Tab. 1. Morphometrics of the holotype (UMMZ 143272), twelve paratypes (UMMZ 143271; USNM 143847) and others 306 individuals. Standard length is expressed in $\mathrm{mm}$.

\begin{tabular}{|c|c|c|c|c|c|c|c|c|c|c|c|c|c|c|c|c|}
\hline & \multirow[b]{2}{*}{ Holotype } & \multicolumn{5}{|c|}{ Paratypes } & \multicolumn{5}{|c|}{ Rio Maquiné } & \multicolumn{5}{|c|}{ Rio Três Forquilhas } \\
\hline & & $\mathrm{N}$ & Min & Max & Mean & $\mathrm{SD}$ & $\mathrm{N}$ & Min & Max & Mean & SD & $\mathrm{N}$ & Min & Max & Mean & $\mathrm{SD}$ \\
\hline Standard length (mm) & 48.68 & 12 & 23.25 & 34.50 & 28.73 & - & 30 & 22.28 & 73.37 & 45.96 & - & 68 & 20.67 & 67.61 & 39.98 & - \\
\hline \multicolumn{17}{|c|}{ Percents of Standard Length } \\
\hline Predorsal length & 51.01 & 12 & 51.01 & 53.57 & 52.21 & 0.84 & 30 & 48.97 & 53.44 & 50.74 & 1.12 & 68 & 48.25 & 54.32 & 51.10 & 1.27 \\
\hline Prepelvic length & 44.36 & 12 & 44.36 & 50.88 & 47.52 & 1.61 & 30 & 45.11 & 50.25 & 47.56 & 1.24 & 67 & 44.93 & 52.34 & 47.61 & 1.32 \\
\hline Prepectoral length & 22.99 & 12 & 23.50 & 25.65 & 24.92 & 0.72 & 30 & 21.72 & 27.74 & 24.33 & 1.68 & 67 & 21.08 & 30.20 & 24.83 & 2.11 \\
\hline Preanal length & 59.85 & 12 & 59.85 & 64.25 & 62.08 & 1.31 & 30 & 58.48 & 66.25 & 63.16 & 1.63 & 68 & 59.16 & 66.32 & 62.72 & 1.45 \\
\hline Body depth & 24.43 & 12 & 24.43 & 27.88 & 26.21 & 0.94 & 30 & 24.37 & 32.55 & 29.03 & 2.25 & 68 & 23.61 & 33.57 & 28.03 & 2.34 \\
\hline Caudal peduncule depth & 8.34 & 12 & 8.34 & 10.20 & 9.28 & 0.57 & 30 & 9.45 & 11.87 & 10.59 & 0.68 & 68 & 8.10 & 12.21 & 10.28 & 0.90 \\
\hline Caudal peduncule length & 15.85 & 12 & 15.85 & 18.55 & 17.39 & 0.92 & 30 & 14.57 & 21.23 & 17.67 & 1.76 & 68 & 9.59 & 20.53 & 17.14 & 1.59 \\
\hline Anal-fin base length & 19.04 & 12 & 21.34 & 27.14 & 23.31 & 1.51 & 30 & 16.85 & 24.97 & 21.32 & 1.66 & 68 & 17.75 & 24.65 & 21.83 & 1.46 \\
\hline Anal-fin depth & 18.18 & 12 & 18.65 & 22.41 & 20.60 & 1.03 & 30 & 15.50 & 21.98 & 18.84 & 1.75 & 68 & 16.29 & 24.34 & 19.57 & 1.71 \\
\hline Dorsal-fin base length & 11.26 & 12 & 11.26 & 14.49 & 12.48 & 1.11 & 30 & 10.82 & 14.86 & 12.72 & 1.34 & 68 & 9.92 & 19.40 & 12.88 & 1.48 \\
\hline Dorsal-fin depth & 21.16 & 12 & 21.33 & 26.86 & 24.60 & 1.78 & 24 & 19.86 & 26.51 & 24.27 & 1.71 & 48 & 21.79 & 34.14 & 24.84 & 1.78 \\
\hline Pelvic-fin length & 13.66 & 12 & 13.79 & 16.99 & 15.38 & 0.99 & 26 & 12.97 & 16.44 & 15.14 & 0.79 & 48 & 11.71 & 16.69 & 14.91 & 1.10 \\
\hline length & 17.36 & 12 & 19.21 & 25.29 & 21.93 & 1.48 & 24 & 16.16 & 22.14 & 20.00 & 1.49 & 47 & 16.17 & 23.29 & 20.06 & 1.61 \\
\hline Head length & 23.15 & 11 & 24.09 & 27.11 & 25.89 & 0.93 & 30 & 22.16 & 27.04 & 25.01 & 1.27 & 68 & 22.30 & 29.79 & 25.47 & 1.75 \\
\hline \multicolumn{17}{|c|}{ Percents of Head Length } \\
\hline Snout length & 22.10 & 12 & 22.10 & 29.12 & 25.91 & 1.85 & 30 & 24.48 & 31.56 & 27.95 & 1.76 & 68 & 22.11 & 36.42 & 26.82 & 2.66 \\
\hline Maxillary length & - & - & - & - & - & - & 30 & 30.79 & 43.37 & 38.08 & 2.47 & 68 & 31.50 & 41.47 & 37.09 & 2.42 \\
\hline Premaxillary length & 13.83 & 12 & 13.83 & 20.98 & 17.41 & 2.27 & 30 & 20.27 & 30.78 & 25.60 & 2.63 & 68 & 16.16 & 32.51 & 23.39 & 3.67 \\
\hline Eye diameter & 39.25 & 12 & 39.25 & 47.86 & 43.55 & 2.56 & 30 & 29.37 & 46.42 & 38.80 & 3.50 & 68 & 21.10 & 50.97 & 40.77 & 3.98 \\
\hline Interorbital & 21.14 & 12 & 21.14 & 30.45 & 27.42 & 2.82 & 30 & 26.06 & 38.07 & 30.83 & 2.62 & 68 & 20.82 & 38.49 & 29.71 & 3.48 \\
\hline Mouth width & - & - & - & - & - & - & 30 & 24.15 & 34.69 & 28.55 & 2.55 & 68 & 21.78 & 37.42 & 28.65 & 3.10 \\
\hline \multicolumn{17}{|c|}{ Counts } \\
\hline Anal-fin branched rays & 15 & 12 & 14 & 16 & 15.17 & 0.72 & 29 & 13 & 18 & 15.72 & 1.19 & 68 & 14 & 19 & 16.01 & 0.98 \\
\hline Dorsal-fin branched rays & 8 & 12 & 8 & 8 & 8.00 & 0.00 & 30 & 7 & 10 & 8.00 & 0.45 & 68 & 7 & 8 & 7.97 & 0.17 \\
\hline Pelvic-fin branched rays & 7 & 12 & 7 & 8 & 7.08 & 0.29 & 30 & 6 & 8 & 6.93 & 0.37 & 68 & 6 & 8 & 6.99 & 0.32 \\
\hline Pectoral-fin branched rays & 10 & 9 & 9 & 12 & 10.67 & 0.87 & 30 & 11 & 13 & 11.90 & 0.71 & 68 & 11 & 13 & 12.01 & 0.44 \\
\hline Caudal-fin branched rays & 19 & 11 & 18 & 19 & 18.73 & 0.47 & 22 & 18 & 19 & 18.95 & 0.21 & 68 & 18 & 19 & 18.96 & 0.21 \\
\hline Lateral line scales & 37 & 12 & 35 & 38 & 37.50 & 0.90 & 27 & 36 & 40 & 37.93 & 1.07 & 60 & 35 & 40 & 37.83 & 0.87 \\
\hline Rows of scales lateral line/dorsal fin & 5 & 12 & 4 & 5 & 4.92 & 0.29 & 28 & 4 & 5 & 4.96 & 0.19 & 65 & 4 & 5 & 4.95 & 0.21 \\
\hline Rows of scales lateral line/pelvic fin & 3 & 12 & 3 & 4 & 3.58 & 0.51 & 28 & 3 & 5 & 3.86 & 0.59 & 65 & 3 & 5 & 3.89 & 0.36 \\
\hline Rows of scales lateral line/anal fin & 4 & 12 & 3 & 4 & 3.75 & 0.45 & 28 & 3 & 4 & 3.82 & 0.39 & 66 & 3 & 4 & 3.91 & 0.29 \\
\hline Predorsal scales & 13 & 12 & 10 & 13 & 11.33 & 0.98 & 30 & 11 & 13 & 11.83 & 0.70 & 68 & 10 & 14 & 12.10 & 0.74 \\
\hline Circunpeduncular scales & 14 & 12 & 14 & 14 & 14.00 & 0.00 & 28 & 13 & 14 & 13.93 & 0.26 & 54 & 13 & 14 & 13.96 & 0.19 \\
\hline Scale sheath on anal-fin base & 5 & 12 & 5 & 7 & 6.42 & 0.79 & 29 & 4 & 7 & 5.83 & 0.97 & 68 & 2 & 7 & 5.57 & 1.23 \\
\hline
\end{tabular}


Tab. 1. (continued)

\begin{tabular}{|c|c|c|c|c|c|c|c|c|c|c|}
\hline & \multicolumn{5}{|c|}{ Rio Mampituba } & \multicolumn{5}{|c|}{ Rio Araranguá } \\
\hline & $\mathrm{N}$ & Min & $\operatorname{Max}$ & Mean & $\mathrm{SD}$ & $\mathrm{N}$ & Min & $\operatorname{Max}$ & Mean & SD \\
\hline Standard length $(\mathrm{mm})$ & 149 & 20.54 & 69.06 & 39.62 & - & 59 & 17.48 & 66.01 & 38.93 & - \\
\hline \multicolumn{11}{|c|}{ Percents of Standard Length } \\
\hline Predorsal length & 149 & 47.94 & 56.47 & 51.43 & 1.38 & 59 & 34.33 & 56.85 & 50.77 & 2.56 \\
\hline Prepelvic length & 149 & 44.67 & 51.99 & 47.79 & 1.61 & 59 & 45.17 & 50.45 & 47.80 & 1.19 \\
\hline Prepectoral length & 149 & 21.64 & 30.45 & 25.00 & 2.18 & 59 & 22.52 & 30.78 & 25.60 & 1.77 \\
\hline Preanal length & 149 & 57.89 & 66.88 & 62.15 & 1.87 & 59 & 57.54 & 66.49 & 62.57 & 1.85 \\
\hline Body depth & 149 & 23.15 & 34.71 & 28.21 & 2.20 & 59 & 20.48 & 32.84 & 27.89 & 2.77 \\
\hline Caudal peduncule depth & 149 & 8.23 & 16.27 & 10.60 & 0.90 & 59 & 7.32 & 12.09 & 10.38 & 1.02 \\
\hline Caudal peduncule length & 149 & 11.78 & 20.84 & 17.31 & 1.25 & 59 & 13.97 & 20.28 & 17.55 & 1.45 \\
\hline Anal-fin base length & 149 & 19.02 & 29.08 & 22.40 & 1.52 & 59 & 17.52 & 27.27 & 21.81 & 1.55 \\
\hline Anal-fin depth & 149 & 13.21 & 25.39 & 19.92 & 1.75 & 59 & 17.22 & 24.64 & 19.82 & 1.51 \\
\hline Dorsal-fin base length & 149 & 8.80 & 17.40 & 12.81 & 1.32 & 59 & 8.44 & 16.20 & 12.65 & 1.42 \\
\hline Dorsal-fin depth & 67 & 21.29 & 40.16 & 25.43 & 2.57 & 10 & 22.60 & 27.29 & 24.57 & 1.47 \\
\hline Pelvic-fin length & 67 & 12.88 & 22.19 & 15.57 & 1.35 & 11 & 14.71 & 17.03 & 15.64 & 0.82 \\
\hline Pectoral-fin length & 66 & 15.81 & 27.59 & 20.51 & 1.69 & 11 & 18.71 & 23.24 & 20.78 & 1.44 \\
\hline Head length & 149 & 22.50 & 28.65 & 25.50 & 1.54 & 59 & 22.99 & 29.57 & 25.57 & 1.21 \\
\hline \multicolumn{11}{|l|}{ Percents of Head Length } \\
\hline Snout length & 149 & 20.21 & 35.87 & 25.83 & 2.24 & 59 & 21.45 & 29.79 & 25.90 & 1.81 \\
\hline Maxillary length & 149 & 27.07 & 42.02 & 36.54 & 2.22 & 59 & 29.65 & 40.03 & 35.77 & 1.99 \\
\hline Premaxillary length & 142 & 15.55 & 30.14 & 22.60 & 3.38 & 59 & 15.28 & 28.92 & 21.06 & 2.70 \\
\hline Eye diameter & 149 & 32.92 & 49.77 & 41.06 & 3.10 & 59 & 32.90 & 50.23 & 41.39 & 3.10 \\
\hline Interorbital & 149 & 22.84 & 48.19 & 31.13 & 3.21 & 59 & 19.05 & 33.30 & 28.87 & 3.09 \\
\hline Mouth width & 149 & 20.00 & 36.66 & 27.81 & 3.46 & 58 & 20.65 & 33.25 & 26.45 & 3.04 \\
\hline \multicolumn{11}{|c|}{ Counts } \\
\hline Anal-fin branched rays & 149 & 13 & 18 & 15.74 & 0.95 & 58 & 14 & 18 & 16.19 & 0.76 \\
\hline Dorsal-fin branched rays & 149 & 7 & 9 & 7.99 & 0.14 & 58 & 7 & 8 & 7.98 & 0.13 \\
\hline Pelvic-fin branched rays & 148 & 6 & 8 & 7.02 & 0.22 & 57 & 6 & 8 & 6.93 & 0.32 \\
\hline Pectoral-fin branched rays & 148 & 10 & 14 & 12.14 & 0.75 & 58 & 10 & 13 & 11.71 & 0.62 \\
\hline Caudal-fin branched rays & 146 & 17 & 20 & 18.99 & 0.22 & 53 & 17 & 20 & 18.96 & 0.34 \\
\hline Lateral line scales & 115 & 36 & 40 & 37.97 & 0.72 & 46 & 34 & 39 & 37.63 & 1.12 \\
\hline Rows of scales lateral line/dorsal fin & 147 & 4 & 6 & 4.99 & 0.16 & 54 & 5 & 6 & 5.02 & 0.14 \\
\hline Rows of scales lateral line/pelvic fin & 143 & 3 & 5 & 3.80 & 0.44 & 54 & 3 & 4 & 3.94 & 0.23 \\
\hline Rows of scales lateral line/anal fin & 141 & 3 & 4 & 3.89 & 0.31 & 53 & 4 & 4 & 4.00 & 0.00 \\
\hline Predorsal scales & 148 & 10 & 14 & 12.05 & 0.77 & 55 & 11 & 14 & 12.16 & 0.81 \\
\hline Circunpeduncular scales & 116 & 12 & 14 & 13.96 & 0.24 & 48 & 14 & 14 & 14.00 & 0.00 \\
\hline Scale sheath on anal-fin base & 146 & 2 & 8 & 5.53 & 1.10 & 55 & 1 & 9 & 5.55 & 1.50 \\
\hline
\end{tabular}

Mouth large, subterminal, lower jaw shorter than upper jaw and upper lip atrophied in large specimens, leaving the premaxillary teeth exposed (Fig. 3). Snout profile rounded. Premaxilla with two tooth rows in small specimens (up to about $30 \mathrm{~mm}$ of SL) and one tooth row in large specimens (more than about $40 \mathrm{~mm} \mathrm{SL}$ ) (Figs. 4-5). Single tooth row corresponding to teeth of both rows merged into single series with more teeth than inner or outer series of teeth counted alone. Merging of tooth rows gradual; specimens with 30 to $40 \mathrm{~mm}$ of SL with well defined double or single series, or in most cases with teeth of inner and outer rows partially merged in single series (Figs. 4-5). When present, inner row with four teeth with five cusps and outer row with three teeth with three cusps; teeth of inner row pedunculate and wider distally than teeth of outer row. Single premaxillary tooth series with seven, rarely five, six or eigth teeth, equal in size, pedunculate and anteroposteriorly compressed, with five cusps and sometimes one tooth with six cusps. Maxilla with three to seven teeth with three to five cusps; number of maxillary teeth increasing with body size (Fig. 5). Last tooth or two posteriormost teeth may be conical in small specimens. In large specimens two anterior maxillary teeth with almost same size of premaxillary teeth and all maxillary teeth exposed (Figs. 3-5). Dentary with eight to eleven teeth, usually with five cusps, decreasing gradually in size posteriorly; last three teeth small with fewer cusps; last one or two teeth conical in some specimens (Fig. 6). 



Fig. 3. Bryconamericus lethostigmus. a. detail of the mouth of a small specimen, with teeth covered by the lips (UFRGS $16083,24.5 \mathrm{~mm} \mathrm{SL})$; $\mathbf{b}$. detail of the mouth of a large specimen with upper lip atrophied and showing the premaxillary teeth (UFRGS 20660, $54.3 \mathrm{~mm} \mathrm{SL).}$

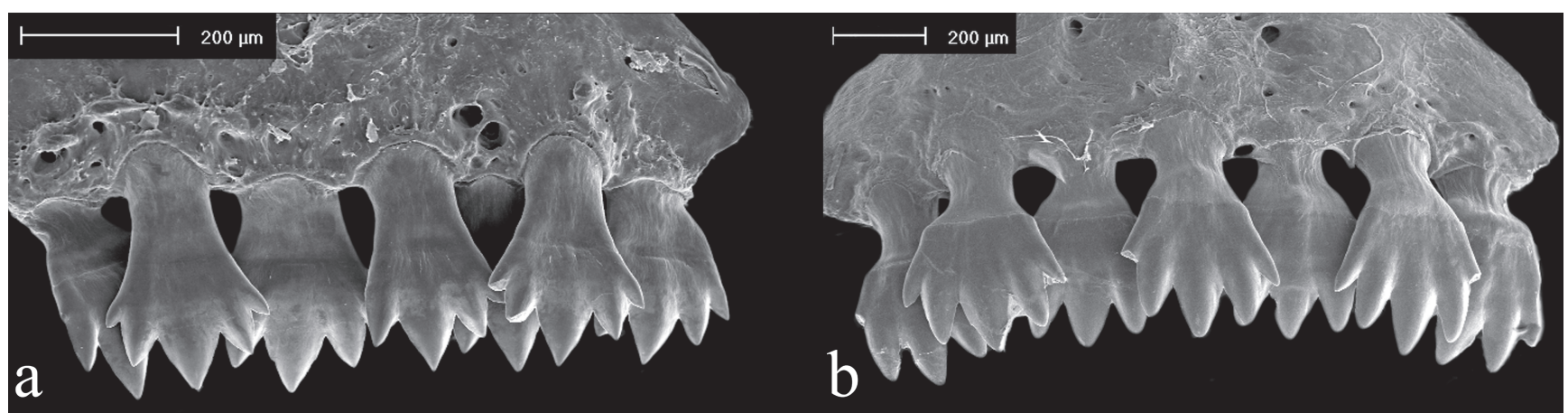

Fig. 4. Bryconamericus lethostigmus. Intermediate stages of ontogenetic changes in the number of tooth rows of the premaxilla with both specimens showing two tooth series. a. smaller specimen with the outer series of teeth larger than those of inner series, and teeth irregularly arranged in two series; b. larger specimen with premaxilla expanded laterally and teeth of the outer and inner series equal in size and interposed at their bases, but not fully forming a single series.
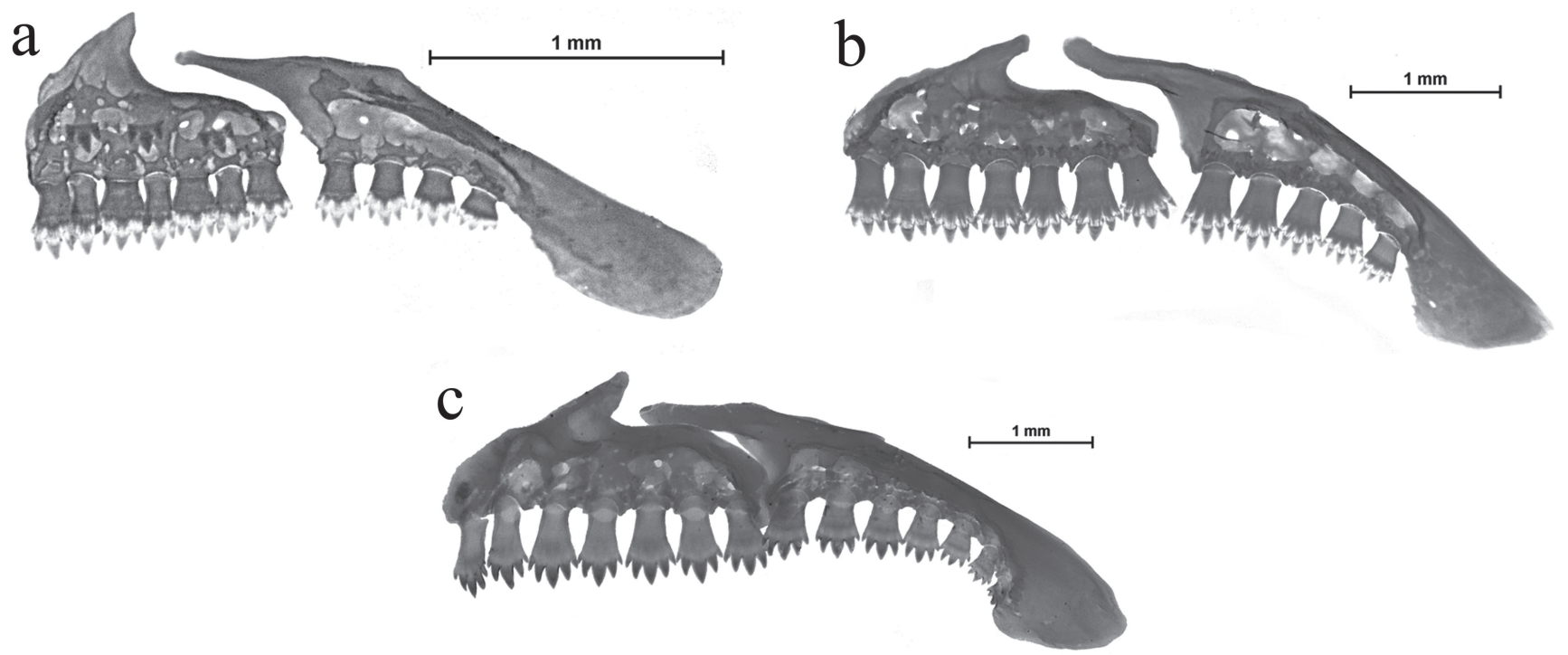

Fig. 5. Ontogenetic changes in the number of tooth rows of the premaxilla, number of teeth in the maxilla and shape of these bones in Bryconamericus lethostigmus. a. $24.1 \mathrm{~mm}$ SL (UFRGS 19488); b. 50.4 mm SL (MCP10774); c. 60.9 mm SL (MCP 19173). 

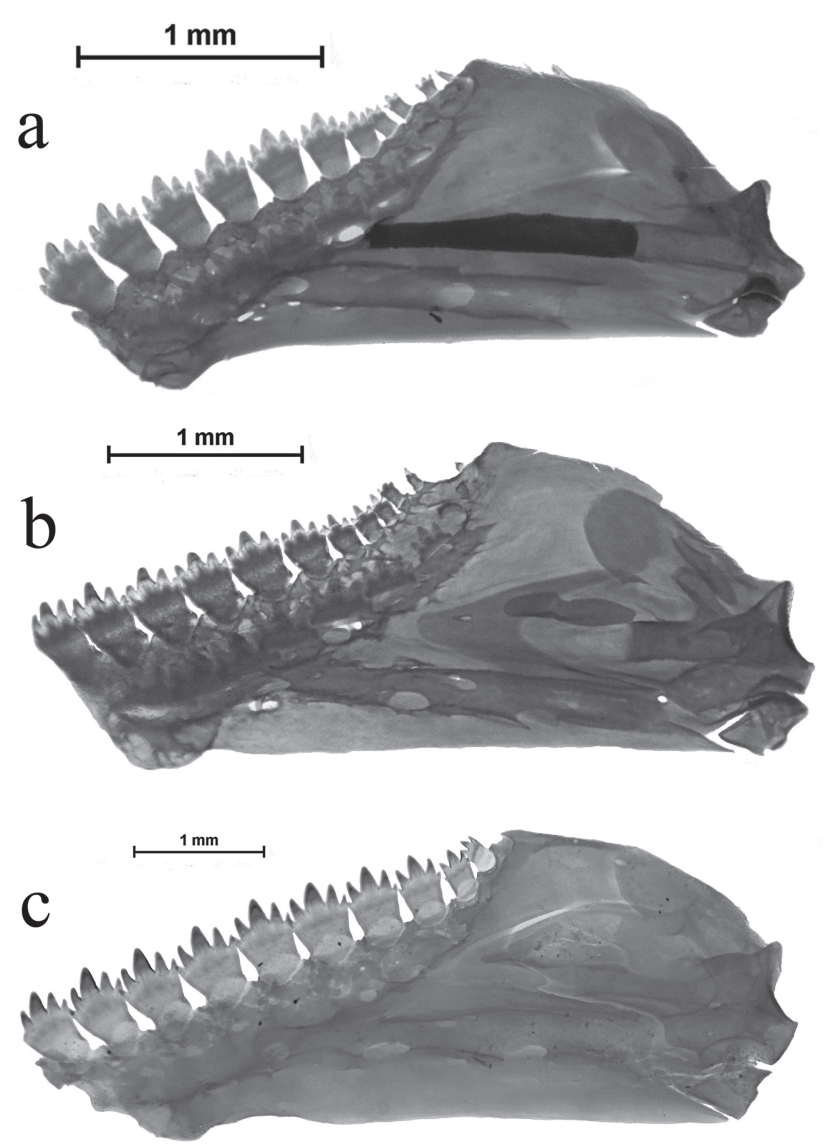

Fig. 6. Ontogenetic changes in the number and size of the teeth of lower jaw and shape of dentary of Bryconamericus lethostigmus. a. $29.7 \mathrm{~mm} \mathrm{SL} \mathrm{(MCP} \mathrm{10774);} \mathrm{b.} 40.3 \mathrm{~mm} \mathrm{SL}$ (UFRGS 19486); c. 60.9 mm SL (MCP 19173).

Dorsal-fin rays ii, 8 rarely 7,9 or $10($ mode $=8 ; n=318)$. Dorsal-fin insertion slightly posterior to ventral-fin origin. Adipose fin present. Anal-fin rays iii-v, usually iv or v, 1319 (mode $=16, \mathrm{n}=317)$. Pectoral-fin rays i, 9-14 rarely 8 or $15($ mode $=12 ; \mathrm{n}=314)$. Pelvic-fin rays i, 6-8 rarely 5 or 9 (mode $=7 ; \mathrm{n}=316$ ). Caudal fin forked, margin of lobes rounded and equal size. Principal caudal-fin rays 19, rarely $17,18$ or 20 (mode $=19 ; \mathrm{n}=301) ; 12-14$ procurrent caudalfin rays dorsally (mode $=14 ; \mathrm{n}=8$ ) and $9-13$ ventrally $($ mode $=12 ; \mathrm{n}=8)$.

Scales cycloid. Lateral line usually complete; number of perforated scales $34-40($ mode $=38, n=261)$. One specimen with 29 perforated scales and one with 32 . Scale rows between dorsal-fin origin and lateral line 4-6 $($ mode $=5, \mathrm{n}$ $=307$ ). Scale rows between lateral line and pelvic-fin origin $3-5($ mode $=4, n=303)$. Scale rows between lateral line and anal-fin origin 3-4 (mode $=4, \mathrm{n}=301)$. Predorsal scales 10 14 (mode $=12, \mathrm{n}=314)$ usually irregularly arranged. Scales sheath along anal-fin base in one row with 1-9 scales (mode $=6, \mathrm{n}=311$ ). Caudal fin not scaled.

Vertebrae: precaudal 16-17 and caudal 19-20 $(\mathrm{n}=7)$. Six vertebrae before first dorsal pterygiophore $(n=8)$. Supraneurals: $5-6(n=7)$.
Statistical results. Some measurements and counts showed significant differences on means among the populations (Tab. 2 ), but without any repeatable pattern to distinguish any or a group of populations from all remaining populations. In agreement to the above mentioned results, PCA revealed no differences on measurements of specimens among populations (Fig. 7). Thus, populations from different river basins showed no morphologically significant differences among them.

Tab. 2. Results of non-parametric significance test (Kruskal Wallis test) from measures and counts that showed significant differences on averages among the Bryconamericus lethostigmus populations. The B. lethostigmus populations are represented as: $\mathrm{ARA}=$ Rio Araranguá; $\mathrm{MAM}=$ Rio Mampituba; FOR $=$ Rio Três Forquilhas and MAQ $=$ Rio Maquiné.

\begin{tabular}{lccc}
\hline $\begin{array}{c}\text { Measurements } \\
\text { and counts }\end{array}$ & $\begin{array}{c}\text { Kruskal- } \\
\text { Wallis chi- } \\
\text { squared }\end{array}$ & p-value & Different populations \\
\hline Dorsal-fin depth & 8.9028 & 0.03061 & ARA x FOR \\
Pelvic-fin depth & 10.478 & 0.01491 & ARA x FOR \\
Pectoral-fin length & 10.41 & 0.01538 & ARA x MAQ \\
Pectoral-fin depth & 9.6833 & 0.02146 & ARA x FOR \\
Maxillary length & 8.4277 & 0.03795 & ARA x MAQ / MAM x MAQ \\
Anal-fin rays & 15.46 & 0.001463 & ARA x MAM / ARA x MAQ \\
Pectoral-fin rays & 23.133 & $3.79 E-05$ & ARA x MAM / MAM x MAQ \\
Caudal-fin rays & 29.916 & $1.44 \mathrm{E}-06$ & MAM x MAQ \\
\hline
\end{tabular}

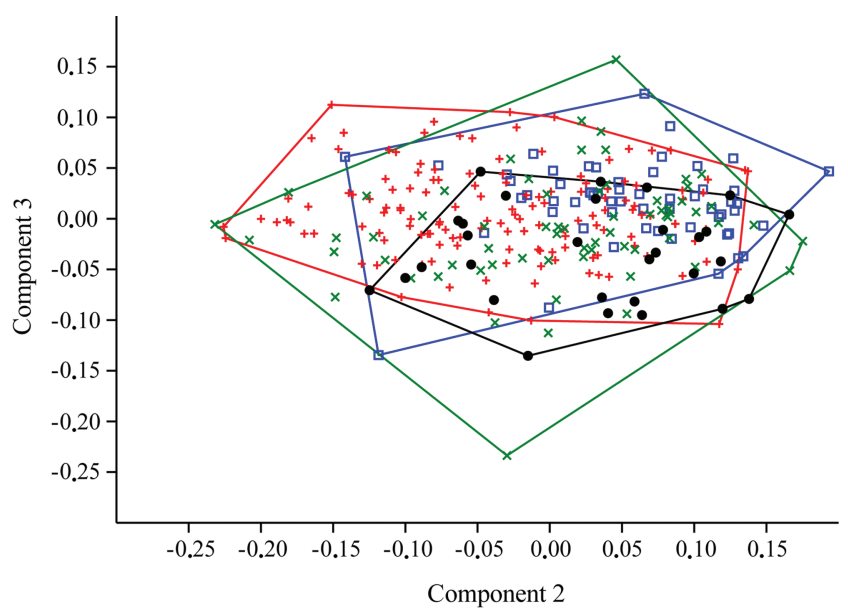

Fig. 7. Principal Component Analysis of log-transformed measurements of the Bryconamericus lethostigmus populations. Blue square = ARA (rio Araranguá); red cross $=$ MAM (rio Mampituba); green cross $=$ FOR (rio Três Forquilhas) and black circle $=$ MAQ (rio Maquiné).

Color in alcohol. General ground body color yellowish olive (Fig. 2a). Dorsum dark gray pigmented from head to caudal peduncle. Top of head on frontals and parietals black pigmented, with deep lying black chromatophores over brain membranes under frontals and parietals and fontanel. Ventral region of head light yellowish; cheek and operculum 
light yellowish with minute black chromatophores concentrated in the upper part of operculum and fifth infraorbital to form indistinct blotch. Numerous dark gray chromatophores, somewhat contiguous, on snout, upper and lower lips. Body sprinkled with minute black points, most numerous above lateral line, concentrated on posterior margin of the scales. Humeral spot conspicuous above fourth, fifth and part of sixth scale of lateral line. All fins with some black chromatophores along fin rays. Caudal fin with black stripe. Body with black line along middle longitudinal body axis, beginning above lateral line and reaching caudal-fin stripe.

Color in life. Life color described from a specimen from rio Tramandaí drainage (Fig. 2b). Dorsal portion of head and body light brown. Lateral and ventral portions of head and body white. Humeral spot black and well defined. Midlateral stripe of the body silvery well defined. Iris light red above the pupil. Yellow pigments on dorsal, adipose, caudal, pectoral and pelvic fins and red pigments on anal fin. White pigment on tip of last unbranched and $1^{\text {st }}$ $2^{\text {nd }}$ branched anal-fin rays, and of unbranched and first branched pelvic-fin rays.

Sexual dimorphism. Males of $B$. lethostigmus differ from females by having hooks on anal- and pelvic-fin rays. Analfin rays with tiny bony hooks present on the first 5 to 7 branched rays. Additional tiny hooks are sometimes present in some of remaining branched rays. Hooks usually present on posterior branches and posterior border of lepidotrichia. Usually one hook per ray segment and absent on unbranched ray. Pelvic fin with tiny bony hooks on posteromedial surface of each ray, one hook per segment and absent on unbranched ray.

Geographic distribution. Bryconamericus lethostigmus is known from the rio Maquiné and rio Três Forquilhas (rio Tramandaí drainage), rio Mampituba and rio Araranguá, Atlantic coastal drainages, Rio Grande do Sul and Santa Catarina States, Brazil (Fig. 1). There is a collection of a single specimen of B. lethostigmus (UFRGS 15385) in the small drainage of the rio Urussanga, the next Atlantic river drainage north of the rio Araranguá.

Ecological notes. Bryconamericus lethostigmus is found in the upper sections of small shallow creeks and rivers draining from Serra Geral formation in rio Maquiné, rio Três Forquilhas, rio Mampituba and rio Araranguá basins. These rivers have clear and cold waters, rapid flow and a rocky bottom. According to Fontana et al. (2003), B. lethostigmus diet may be composed of periphyton due to the regression of the upper lip. Stomach contents of three large specimens consisted of a lot of algae (filamentous algae and diatom), some larvae and pupa of Diptera (Psychodidae), larvae of Chironomidae and larvae of Trichoptera. The presence of these items also indicates a diet composed mostly of periphyton. Stomach contents of four small specimens consisted of highly particulate non-identifiable organic matter (animal or plant origin) with sediment (sand) and presence of filamentous algae and diatom. Vogel (2012) estimated that $58 \mathrm{~mm}$ Total Length (TL) is the size at first maturity to $B$. lethostigmus and also that $70 \mathrm{~mm} \mathrm{TL}$ is the size that all are able to reproduce.

Conservation status. The populations from the rio Tramandaí and Mampituba drainages were included in the list of endangered species from Rio Grande do Sul State, Brazil, and categorized as Vulnerable - VU, according to IUCN criteria (Marques et al., 2002: 28; Reis et al., 2003: 127) mainly due to habitat degradation. In the lastest list of endangered species from Rio Grande do Sul State, Brazil, $B$. lethostigmus was not classified in any threatened categories (Rio Grande do Sul, 2014) given that its population is apparently stable and no eminent threats were identified. The populations from the rio Araranguá, rio Urussanga and Mampituba drainages were not included in the list of threatened species from Santa Catarina State (CONSEMA, 2011). This species was also not included in the national list of threatened species (MMA, 2014).

We have tried to collect additional specimens of $B$. lethostigmus in the rio Urussanga and tributaries, the northernmost record of the species, but we were unable to find new specimens in this drainage. This river basin is currently very impacted by coal mining activities, which may affect the occurrence of the species.

Molecular results. A total alignment of 1,700 base pairs (bp) was obtained for the mitochondrial genes (COI, $676 \mathrm{bp}$ and ND2, 1,024 bp). Nucleotide and haplotype diversity were 0.0029 and 0.98 , respectively. A total of 57 polymorphic sites defining 38 different haplotypes for $B$. lethostigmus were found. Neutrality tests were significant, rejected the null hypothesis of constant population size and/or no natural selection (Tajima's D -2.3318, $P<0.01$; Fu's FS $-25.65, P<0.01)$. We obtained an alignment of 328 bp for $S 72,700$ bp for $S H 3 P X 3$, and 759 bp for Myh6, but no variability was observed and, therefore, excluded from further analyses. New sequences generated in this study were submitted to GenBank (KX815171 to KX815260).

Mitochondrial data showed no association between haplotypes and drainages (Fig. 8) and no strong genetic structure among predefined populations. The haplotype network does not show any phylogenetic structure, and most haplotypes are connected by one or two mutations. However, there are no shared haplotypes among drainages, except for two haplotypes shared between FOR and MAM. Thus, the lack of geographic structure is due to a shallow genealogical structure rather than shared haplotypes. In agreement to the haplotype network, the AMOVA (Tab. 3) showed low isolation among river systems for the mtDNA data $\left(\mathrm{F}_{\mathrm{ST}}=0.08\right)$. Mitochondrial DNA genetic distance among populations (about $0.3 \%$ ) was also very low (Tab. 4). 


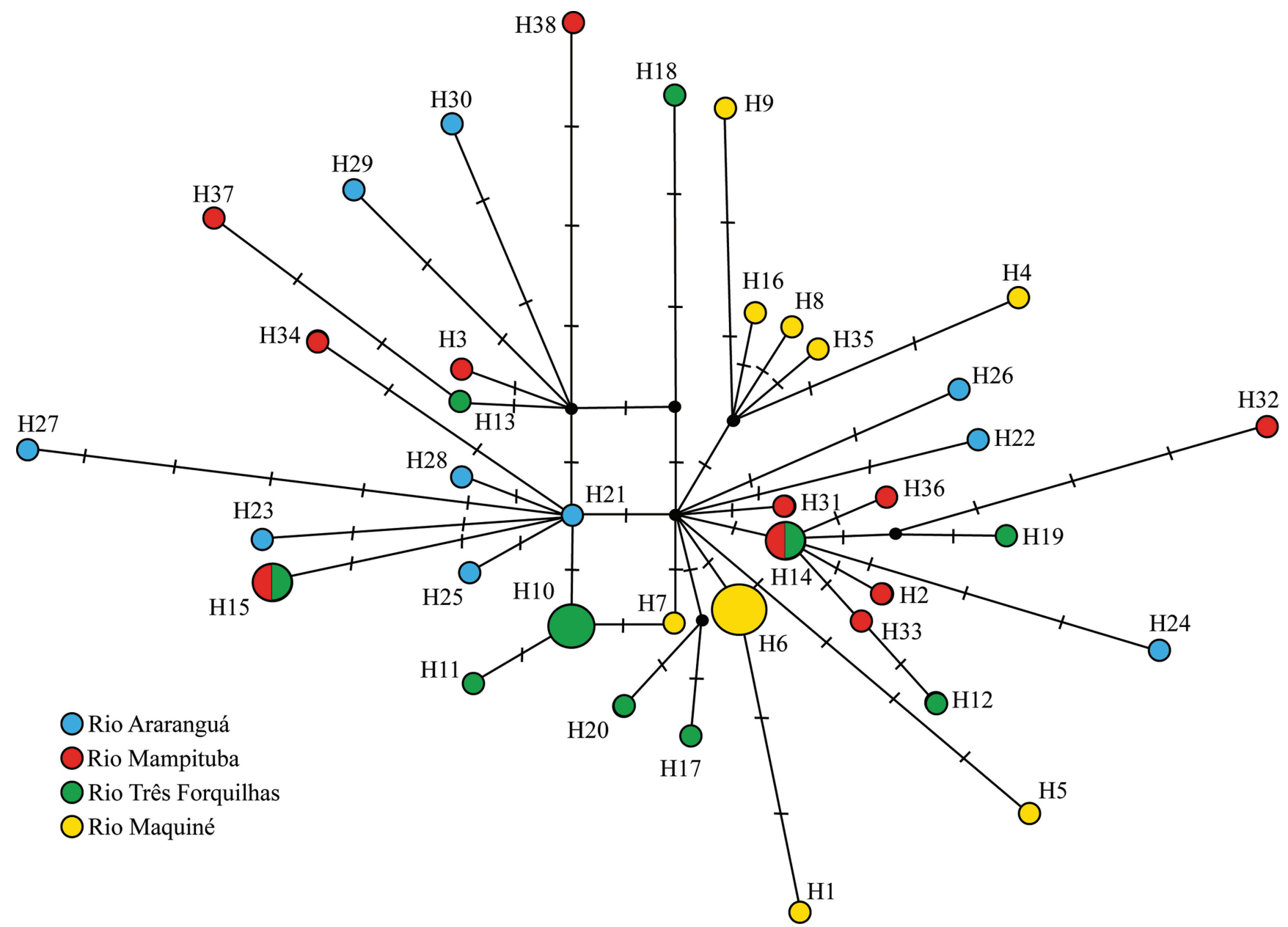

Fig. 8. Median-joining networks among haplotypes of Bryconamericus lethostigmus samples inferred by the concatenated mtDNA dataset $(C O I+N D 2)$. Each circle represents a unique haplotype with circle sizes being proportional to their frequencies. Each colour represents a population. Crossed markers indicate the number of mutations between haplotypes.

Tab. 3. Results of the analysis of molecular variance (AMOVA) among and within Bryconamericus lethostigmus populations for the mtDNA data.

\begin{tabular}{lccc}
\hline \multirow{2}{*}{ Source of variation } & \multicolumn{3}{c}{ mtDNA } \\
\cline { 2 - 4 } & d.f & \% variation & p-value \\
\hline Among populations & 3 & 8.35 & $<0.001$ \\
Within populations & 41 & 91.65 & $<0.001$ \\
\hline Fixation Index $\boldsymbol{\Phi}$ & \multicolumn{2}{c}{0.08347} & $<0.001$ \\
\hline
\end{tabular}

Tab. 4. Genetic distance matrix for mitochondrial data using the Kimura 2-parameter (K2P) among Bryconamericus lethostigmus populations. The B. lethostigmus populations are represented as: $\mathrm{ARA}=$ Rio Araranguá; $\mathrm{MAM}=$ Rio Mampituba; FOR $=$ Rio Três Forquilhas and MAQ $=$ Rio Maquiné.

\begin{tabular}{lcccc}
\hline & ARA & MAM & FOR & MAQ \\
\hline ARA & 0 & & & \\
MAM & 0.003 & 0 & & \\
FOR & 0.003 & 0.003 & 0 & \\
MAQ & 0.003 & 0.003 & 0.003 & 0 \\
\hline
\end{tabular}

The mtDNA coalescence time of B. lethostigmus was around 0.34 millions of years ago (Ma) (95\% Highest Posterior Density [HPD] 0.15-0.58 Ma), significantly more recent than the estimate for $D$. itaimbe, which was around 2 Ma (95\% HPD 0.97-3.5 Ma). The coalescence time for the MAM+FOR group was very similar for both species $(0.32$ Ma - 95\% HPD 0.14-0.56 Ma; and 0.31Ma - 95\% HPD 0.12$0.55 \mathrm{Ma}$ for $B$. lethostigmus and D. itaimbe, respectively). Effective population size estimates were similar for both species, being 1.2 million (95\% HPD 0.55-2.23 million) effective females for B. lethostigmus and 0.86 million $(95 \%$ HPD 0.40-1.63 million) effective females for D. itaimbe.

Material examined. Odontostoechus lethostigmus (Gomes, 1947). All from Brazil. Rio Maquiné basin, type-specimens: UMMZ 143272, 1, $48.68 \mathrm{~mm}$ SL, holotype, Rio Grande do Sul, rio Maquiné; UMMZ 143271, 11, 23.25-34.05 mm SL, paratype, Rio Grande do Sul, rio Maquiné; USNM 143847 [ex UMMZ 143271] 1, 29.97 mm SL, paratype, Rio Grande do Sul, rio Maquiné. Rio Maquiné basin, non-type specimens: UFRGS 3336, 2, 62.65-63.15 mm SL, Rio Grande do Sul, rio Maquiné, under the bridge near Maquiné city, 
2904'S, 50¹1'W; UFRGS 4377, 2, 35.23-37.8 mm SL, Rio Grande do Sul, rio Maquiné, under the bridge near Maquiné city, $29^{\circ} 04^{\prime} \mathrm{S}$, 50¹1'W; UFRGS 4378, 2, 34.37-37.72 mm SL, Rio Grande do Sul, rio Maquiné, under the bridge near Maquiné city, $29^{\circ} 04^{\prime} \mathrm{S}, 50^{\circ} 11^{\prime} \mathrm{W}$; UFRGS 4416, 1, $35.97 \mathrm{~mm}$ SL, Rio Grande do Sul, rio Maquiné, 2904'S, 50¹1'W; UFRGS 4501, 1, 65.44 mm SL, Rio Grande do Sul, arroio do Ouro, between Maquiné and Barra do Ouro, 29³4'S, 50¹5'59'W; UFRGS 4524, 2, 71.92-73.37 mm SL, Rio Grande do Sul, arroio do Ouro, between Maquiné and Barra do Ouro, 29³4'S, 50¹5'59'W; UFRGS 12086, 1 (TEC1233A), Rio Grande do Sul, rio Maquiné, Maquiné city, 29³9'07'S, 50¹2’34”W; UFRGS 16198, 2 (TEC 2277, 2279), Rio Grande do Sul, rio Maquiné, Maquiné city, 29³8'50.8” S, 50¹3'02.0”W; UFRGS 16199, 1 (TEC 2313), Rio Grande do Sul, rio Maquiné, Maquiné city, 29³4'12.8” S, 50¹6'47.7'W; UFRGS 16200, 6 (TEC 2314, 2315, 2316, 2318, 2319, 2323), Rio Grande do Sul, rio Maquiné, Maquiné city, 29³5'14.7'S, 50¹6'13.1'W; UFRGS 16207, 1 (TEC 2349A), Rio Grande do Sul, rio Maquiné, Maquiné city, 29³7’39.1’S, 50¹4'31.1'W; UFRGS 16208, 1 (TEC 2351), Rio Grande do Sul, rio Maquiné, Maquiné city, 29³8'50.8'S, 50¹3'02.0”W; MCP 13657, 4, 30.17-36.96 mm SL, Rio Grande do Sul, rio Maquiné, Maquiné city, 29³9'59'S, 50¹2'W; MCP 14645, 2, 42.67-46.76 $\mathrm{mm}$ SL, Rio Grande do Sul, rio Maquiné, Maquiné city, 2950'S, 50²1'W; MCP 13608, 4, 42.45-63.85 mm SL, Rio Grande do Sul, rio Maquiné, Maquiné city, 29³9'59'S, 50¹1'W; MCP 26965, 5, 22.28-68.18 mm SL, Rio Grande do Sul, Maquiné city, 2940'37''S, 50¹2’30"W. MCP 10776, 5, (2 c\&s) 40.75-55.19 mm SL, Rio Grande do Sul, rio Maquiné, Maquiné city, 2938'59'S, 50¹3'W; MCP 10774, 4 (c\&s), 29.77-50.43 mm SL, Rio Grande do Sul, arroio Água Parada, Maquiné city, 2940'30'S, 50¹1'57'W. Rio Três Forquilhas basin: UFRGS 2998, 9, 39.33-44.14 mm SL, Rio Grande do Sul, rio Três Forquilhas, 2931'59"S, 5004'59"W; UFRGS 5056, 3, 65.37-67.61 mm SL, Rio Grande do Sul, rio Três Forquilhas in Vila Boa União, 29³1'59'S, 5004'59'W; UFRGS 6309, 2, 55.44-67.36 mm SL, Rio Grande do Sul, rio Três Forquilhas in Vila Boa União, 29²8'18'S, 5006'59'"W; UFRGS 6644, 6, 34.53-40.9 mm SL, Rio Grande do Sul, rio Três Forquilhas in Vila Boa União, 2928'18'S, 5006'59'W; UFRGS 12736, 2, 23.63$45.57 \mathrm{~mm}$ SL, Rio Grande do Sul, rio Três Forquilhas under the high bridge, 29³0'32'S, 5005'30"W; UFRGS 16204, 3 (TEC 2331, 2333, 2338), Rio Grande do Sul, rio Três Forquilhas, 29³0'32.4”S, 5005'29.8'W; UFRGS 16206, 4 (TEC 2343, 2344, 2345, 2346), Rio Grande do Sul, rio Três Forquilhas, 29³2’27.8’'S, 5004'48.0”'W; UFRGS 16209, 4 (TEC 2357, 2358, 2359, 2360), Rio Grande do Sul, rio Três Forquilhas, 29³0'32.4”S, 5005'29.8'W; UFRGS 16210, 1 (TEC 2374), Rio Grande do Sul, rio Três Forquilhas, 29²8'21.1'S, 5007'09.9'W; UFRGS 20710, 2, 23.04-58.12 mm SL, Rio Grande do Sul, rio Três Forquilhas, 29³0'32.4”S, 5005'29.8'W; MCP 25304, 3, 21.63-40.39 mm SL, Rio Grande do Sul, Terra de Areia city, 29³1'01'S, 5006'40"W; MCP 25288, 4, 25.3-45.84 mm SL, Rio Grande do Sul, rio Três Pinheiros, 29³1'36"S, 5006'21'W; MCP 14314, 6, 32.55-47.44 mm SL, Rio Grande do Sul, rio Três Forquilhas, 29²4'59"S, 50¹0'W; MCP 25332, 12, 20.67-44.95 mm SL, Rio Grande do Sul, rio Três Forquilhas, 29³0'43"'S, 5005'31'”W; MCP 14802, 5, 37.87-44.95 mm SL, Rio Grande do Sul, rio Três Forquilhas,
29³1'36"'S, 5006'19"W; MCP 25673, 8, 33.49-45.28 mm SL, Rio Grande do Sul, rio Três Forquilhas, 29³1'59'S, 5004'59'W; MCP 21322, 6, 58.25-66.04 mm SL, Rio Grande do Sul, rio Três Forquilhas, 29²5'59"S, 5006'59'W; MCP 10811, 2 (c\&s), 58.95 mm SL, Rio Grande do Sul, rio Três Forquilhas, 29³1'59"'S, 5003'59"W. Rio Mampituba basin: UFRGS 11080, 2, 51.99$56.19 \mathrm{~mm}$ SL, Santa Catarina, rio Mampituba, on balneary in Praia Grande, 29¹1'57'S, 4957'05'W; UFRGS 12537, 1 (TEC 1239A), Santa Catarina, Praia Grande, rio Mampituba, 29¹4'49”S, 5004'12”W; UFRGS 12723, 1 (TEC 1460A), Rio Grande do Sul, Vila São João, rio Mampituba, 29¹4'56.8”'S, 4950'55.5”W; UFRGS 15356, 1, 51.99 mm SL, Rio Grande do Sul, Arroio Paraíso, Morro Azul, 29²3'55'S, 4955'01' 'W; UFRGS 16083, 1, 25.99 mm SL, Rio Grande do Sul, Vila São João, rio Mampituba, 29¹4'57'S, 4950'55'W; UFRGS 16213, 5 (TEC 2491, 2493, 2494 2495, 2497), Santa Catarina, Praia Grande, rio Canoas, 29¹3'35.6”S, 5000'11.9'W; UFRGS 16226, 4 (TEC 2618, 2620, 2621, 2624), Santa Catarina, Praia Grande, rio Canoas, 29¹1'22.0”S, 4954'12.1'W; UFRGS 19487, 2, 51.63-57.03 mm SL, Rio Grande do Sul, Morrinhos do Sul, arroio Paraíso, 29²3'53"S, 4955'01 "W; UFRGS 19486, 22, (1 c\&s) 22.43-40.39 $\mathrm{mm}$ SL, Rio Grande do Sul, Vila São João, rio Mampituba, 2914'57'S, 4950'55'W; UFRGS 19488, 18, (1 c\&s), 20.54$47.24 \mathrm{~mm}$ SL, Rio Grande do Sul, Torres, rio Mampituba, 29¹3'14'S, 4952'49' W; UFRGS 20646, 2, 40.12-43.18 mm SL, Rio Grande do Sul, Torres, rio Mampituba, 29¹3'14.1'S, 4952'49.2”W; UFRGS 20647, 10, 22.82-54.83 mm SL, Rio Grande do Sul, Torres, rio Mampituba, 29¹3'14.1'S, 4952'49.2”W; UFRGS 20648, 1, 55.27 mm SL, Rio Grande do Sul, Morrinhos do Sul, arroio Paraíso, 29²3'53'S, 4955'01'W; UFRGS 20649, 3, 23.48-41.68 mm SL, Rio Grande do Sul , Vila São João, rio Mampituba, 29¹3'14.1'S, 4952'49.2'W; UFRGS 20650, 2, 35.946.62 mm SL, Rio Grande do Sul, Morrinhos do Sul, arroio Paraíso, 29²3'53"S, 4955'01'"W; UFRGS 20652, 2, 46.88-49,41 mm SL, Rio Grande do Sul, Morrinhos do Sul, arroio Paraíso, 29²3'53'S, 4955'01"W; UFRGS 20653, 4, 49.07-58.42 mm SL, Rio Grande do Sul, arroio Paraíso, 29²3'53”'S, 4955'01'W; UFRGS 20654, 2 , 51.8-69.06 $\mathrm{mm}$ SL, Rio Grande do Sul, rio Mampituba, 29॰13'14.1'S, 4952'49.2”W; UFRGS 20655, 16, 29.06-52.34 mm SL, Santa Catarina, Praia Grande, rio Mampituba, 29¹4'49's, 5004'11.6”'W; UFRGS 20656, 4, 43.54-55.06 mm SL, Rio Grande do Sul, Morrinhos do Sul, arroio Paraíso, 29²3'53'S, 4955'01'W; UFRGS 20657, 8, 49.73-61.14 mm SL, Santa Catarina, Praia Grande, rio Mampituba, 29¹4'49”S, 5004'11.6”W; UFRGS 20658, 5, 30.05-45.16 mm SL, Rio Grande do Sul , Vila São João, rio Mampituba, 29¹3'14'S, 4952'49'W; UFRGS 20659, 2, 32.3743.82 mm SL, Rio Grande do Sul, Morrinhos do Sul, arroio Paraíso, 29²3'53"S, 4955'01'"W; UFRGS 20660, 12, 42.7-65.85 mm SL, Rio Grande do Sul, Morrinhos do Sul, arroio Paraíso, 29²3'53”S, 4955'01'W; UFRGS 20708, 4, 28.09-41.11 mm SL, Rio Grande do Sul, Vila São João, rio Mampituba, 29¹4'56.8”'S, 4950'55.5”'W; UFRGS 20709, 6, 38.01-45.89 mm SL, Rio Grande do Sul, rio Mampituba, 2913'14'S, 4952'49'W; UFRGS 20711, 2, 59.08$60.07 \mathrm{~mm}$ SL, Rio Grande do Sul, Morrinhos do Sul, arroio Paraíso, 29²3'55.3"S, 4955'01.1'W; UFRGS 20712, 3, 49.47-61.51 mm SL, Rio Grande do Sul, Morrinhos do Sul, arroio Paraíso, 
29²3'55.3"S, 4955'01.1'W; UFRGS 20713, 1, 47.48 mm SL, Rio Grande do Sul, rio do Mengue, 29¹7'34.7’'S, 4955'17.3”W. Rio Araranguá basin: UFRGS 10553, 3, 20.97-30.74 mm SL, Santa Catarina, Siderópolis, rio Jordão; UFRGS 15391, 10, 38.26-46.3 $\mathrm{mm}$ SL, Santa Catarina, Meleiro, rio Itoupava, 28 $35^{\prime} 14^{\prime \prime} \mathrm{S}$, 49²9'23'"W; UFRGS 15401, 20, (2 c\&s) 24.91-54.51 mm SL, Santa Catarina, Nova Veneza, rio São Bento, 28 36'45'S, 49³3'07'W; UFRGS 16211, 6 (TEC 2375, 2377, 2378, 2379, 2380, 2381), Santa Catarina, Ermo, rio Itoupava, $28^{\circ} 58^{\prime} 43.5^{\prime \prime} \mathrm{S}$, 4940'25.0”'W; UFRGS 16212, 4 (TEC 2427, 2430, 2431, 2436), Santa Catarina, Siderópolis, rio São Bento, 28³6'35.0”S, 49³3'16.2”'W; MCP 23595, 11, 17.48-51.3 mm SL, Santa Catarina, Ermo, rio Itoupava, 2858'43"S, 4940'25'W; MCP 19173, 7, (1 c\&s), 29.96-60.96 mm SL, Santa Catarina, Ermo, rio Itoupava, 2859'11"S, 4940'40"W; MCP 19169, 5, 44.58-60.42 mm SL, Santa Catarina, Meleiro, rio São Francisco, 28 42'S, 4940'40'W; MCP 25436, 2, 25.12-66.01 mm SL, Santa Catarina, Ermo, rio Itoupava, 2858'43'S, 4940'25'W; MCP 43602,1, $50.1 \mathrm{~mm}$ SL, Santa Catarina, Ermo, rio Itoupava, 28 59'11's, 4940'40'”W. Rio Urussanga basin: UFRGS 15385, 1, $39.01 \mathrm{~mm}$ SL, Santa Catarina, Urussanga, rio Cocal, 2830'28'S, 49¹8'55' W.

\section{Discussion}

Both morphological and molecular data refute the hypothesis that the population from the rio Araranguá possibly constitutes a new species (contra Malabarba, 1998). We have found no clear morphological differences to distinguish the rio Araranguá or any of the studied populations from all other populations. We found statistical differences in the mean of some measurements or counts in pairwise comparisons, but these differences were not consistent among all populations to allow the diagnosis of any distinct population (Tab. 2). For example, the mean dorsal-fin depth is statistically different between the rio Araranguá and rio Três Forquilhas populations, but does not distinguish any of these populations from both the rio Maquiné and rio Mampituba populations. The shallow genealogical depth of the mtDNA combined with its lack of geographic structure, and the lack of genetic variation in the nuclear markers are also strong indicators that all $B$. lethostigmus populations constitute a single species.

Genetic Structure and Evolutionary History. Considering that $B$. lethostigmus and D. itaimbe occur in the same drainages, are syntopic, and share a similar life history, the different phylogeographic pattern found for both species is striking. While $D$. itaimbe shows a strong genetic structure with well-defined mtDNA clades (Hirschmann et al., 2015), $B$. lethostigmus showed no genealogical structure, and only a very weak genetic structure based on mtDNA data. Such phylogeographic difference between these species may be explained by three different scenarios, or a combination of them: (1) Different mtDNA evolutionary rates between the two species; (2) Different colonization times of the two species in these drainages; and (3) Gene flow among
B. lethostigmus populations through paleaodrainages hampering population structure.

Given the differences on time to most recent common ancestor (TMRCA) for mtDNA, but the similar historical effective population size estimates, one could propose that $B$. lethostigmus had a mtDNA evolutionary rate ten times slower than D. itaimbe. Nabholz et al. (2008, 2009) showed that mtDNA evolutionary rate, based on cytochrome b sequence, exhibit a thirty-fold range variation across bird lineages and of hundred-fold variation across mammal lineages. However, such wide evolutionary rate variation was found among distinct taxonomic groups showing differences in generation time and metabolic rate. On the other hand, B. lethostigmus and D. itaimbe are relatively closely related species, with similar generation time and metabolic rates. Tringali et al. (1999) found only a 0.5 -fold difference in mtDNA evolutionary rate for fish species of the same genus. Thus, a difference on evolutionary rate among $B$. lethostigmus and $D$. itaimbe seems an unlikely explanation for their distinct phylogeographic patterns.

Therefore, if these two species have similar mtDNA evolutionary rates, they probably had different evolutionary histories, as illustrated by their different TMRCA for mtDNA lineages, despite the similar historical effective population sizes. One possibility is that the ancestor of these two species colonized these drainages in different periods. The ancestor of $D$. itaimbe may have arrived in this ecoregion around 2 $\mathrm{Ma}$, while the ancestor of $B$. lethostigmus only arrived around $0.34 \mathrm{Ma}$, and therefore, the lack of genetic structure among $B$. lethostigmus population may be due, at least in part, to a shorter period of evolutionary time. The ancestors may have reached their current distribution by headwater capture or through potential connections on the coastal plain during marine regressions. Based on present data it is not possible to state which dispersal route was followed by these species.

Another possibility for the lack of genetic structure in $B$. lethostigmus is a more intense gene flow among populations over time through palaeodrainages during the marine regressions compared to $D$. itaimbe. The reconstruction of palaeodrainage availability over time (Fig. 9) suggests that these drainages have been isolated only a short period of time, whereas during most of the time, these drainages had connections, as demonstrated by Thomaz et al. (2015b). Under this hypothesis, $B$. lethostigmus would be more efficient in maintaining genetic connectivity among populations than $D$. itaimbe. A caveat to this hypothesis is that if this species had used it these connections until very recently, this would result in a larger amount of shared haplotypes among drainages, which was not observed. There are two mitochondrial haplotypes shared between FOR and MAM populations of $B$. lethostigmus, while the other populations share no haplotypes. This is the same pattern observed for D. itaimbe. This common pattern of haplotype sharing observed for both species may be related to a single event that allowed gene flow between these two drainages, most probably headwater capture (Hirschmann et al., 2015), a process still active in the 
rivers of the coastal region (Ribeiro, 2006). According to our results, this event may have occurred around $0.3 \mathrm{Ma}$, probably close to the dispersal of the ancestor of $B$. lethostigmus across coastal drainages.

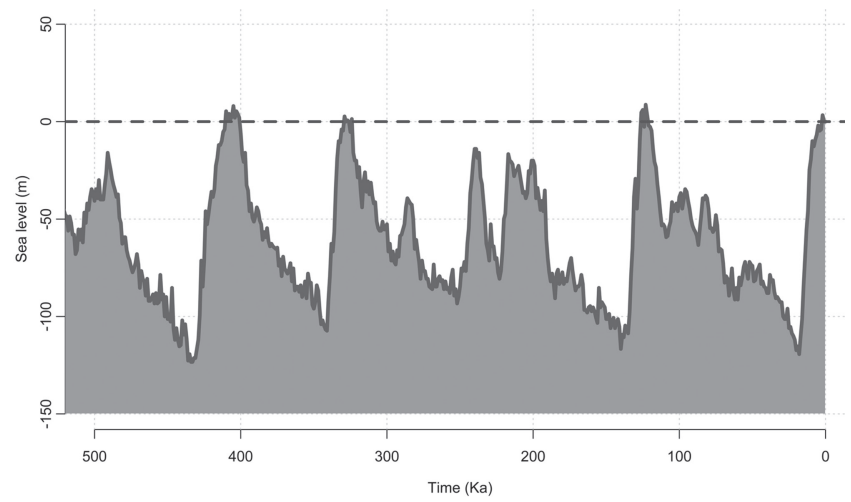

Fig. 9. Variation in sea level for the last $500 \mathrm{ka}$ shown according to Miller et al. (2011).

The hypothesis of headwater capture instead of dispersion through low land connections to explain the sharing haplotypes between the rio Três Forquilhas and rio Mampituba may be further supported by the lack of shared haplotypes between FOR and MAQ populations, which are currently connected through freshwater lagoons. The region is widely visited for field work, and there are no capture records for this species in lagoons. Therefore, it is likely that lagoons act as barrier to dispersion of B. lethostigmus between river systems similarly to what was proposed for $D$. itaimbe (Hirschmann et al., 2015).

Mouth Morphology. The presence of a single tooth series in the premaxilla has been a key character in Eigenmann's (1915) definition of the characid subfamily Cheirodontinae, that have had up to 56 genera assigned along its history (Malabarba, 1998: appendix B), including Odontostoechus. The single tooth series in the premaxilla, however, has been demonstrated by direct homology (Malabarba, 1998) or by parsimony analyses (e.g. Paracheirodon Géry by Weitzman, Fink, 1983; Charax Gronow by Lucena, 1987; "the Rosy Tetras Clade" by Weitzman, Palmer, 1997; Xenurobryconini by Weitzman, Fink, 1985; Netto-Ferreira et al., 2013) to originate several times and independently in different genera of the Characidae.

Malabarba (1998) identified three non-homologous origins of a single tooth series in Characidae: (1) the merging of both rows into a single one; (2) the reduction of the anterior tooth row, with one or even two teeth remaining and not perfectly aligned in a single series; and, (3) the complete loss of the anterior tooth row. According to Malabarba (1998) the single tooth row in the B. lethostigmus originated with the merging of the external tooth row and the inner row during ontogeny. As such this character is non-homologous with the single tooth row observed ontogenetically in Cheirodontinae. This observation is corroborated in this study where we provided the description and illustration of the merging of the two tooth rows in a single series along ontogenetic development without tooth loss in $B$. lethostigmus (Figs. 4-5).

Among stevardiines, relationships of B. lethostigmus have been alternatively assigned to two groups of genera. Phylogenies based on comprehensive samples of characid taxa (Mirande, 2010; Javonillo et al., 2010; Oliveira et al., 2011; Thomaz et al., 2015a) have found the type-species of Odontostoechus grouped to at least one representative of the genus Bryconamericus sensu stricto (Thomaz et al., 2015a), including the genera Hypobrycon and Nantis (currently junior synonyms of Bryconamericus). Alternatively, scenarios based on primary hypotheses of homology through direct comparisons of characteres related to mouth morphology have resulted in completely different hypotheses, grouping $B$. lethostigmus to genera such as Bryconacidnus, Ceratobranchia, Monotocheirodon, Othonocheirodus, Rhinopetitia, and Rhinobrycon (Böhlke, 1954; Menezes et al., 2013; Netto-Ferreira et al., 2014). However, these hypotheses are based on direct observations and have not been subjected to congruence tests of homology (de Pinna, 1991).

We herein refute the hypothesis of primary homology between mouth modifications found in B. lethostigmus and in the stevardiine genera Bryconacidnus, Ceratobranchia, Monotocheirodon, Otonocheirodus, Rhinopetitia, and Rhinobrycon. The tooth row reduction in the premaxilla during ontogeny observed in B. lethostigmus represents a unique condition among the Stevardiinae. The juvenile stage in B. lethostigmus, characterized by two premaxillary tooth series, is identical and homologous to the juvenile and adult stages in the species of Bryconamericus sensu stricto. The adult stage in $B$. lethostigmus, however, is characterized by a single tooth series that includes the teeth of both rows merged, is a novelty and an autapomorphy of this species. It can be characterized both by the heterochronic process of peramorphosis related with the addition of one step on the development of the premaxilla as well as by heterotopy by the changes in the spatial distribution of the teeth of the inner and outer series in a final stage of growth (Zelditch, Fink, 1996). We can recognize the final condition in $B$. lethostigmus is the result of a causal sequence of events (merging tooth series) - feature A induces feature B - and it is not only a temporal change.

Although mouth shape in adult $B$. lethostigmus remarkably resembles that of Monotocheirodon (Menezes et al., 2013: figs. 2, 10,14) they have different origins and are homoplastic. The mouth modifications in Monotocheirodon species does not originate from ontogenetic changes in mouth morphology. Instead, the single tooth series in the premaxilla of Monotocheirodon species apparently originates from the complete loss of the external tooth series, since all the species retain a single series of four teeth that seems to be homologous to the four teeth in the inner premaxillary tooth series found in the stevardiines (Menezes 
et al., 2013, fig. 14, illustrated three premaxillary teeth in Monotocheirodon kontos, but the description refers to the presence of four teeth in all specimens).

Another diagnostic character of $B$. lethostigmus is the upper lip atrophied in large specimens, leaving the premaxillary teeth exposed. Its popular name, "smiling tetra", was due to this character. However, as this character is apparent only in large specimens, young and small specimens do not "smile". The atrophied upper lip is shared with Deuterodon stigmaturus (Gomes), which is sympatric to B. lethostigmus, D. rosae (Steindachner), Henochilus wheatlandii Garman, Psalidodon gymnodontus Eigenmann, Bryconacidnus, Ceratobranchia, Monotocheirodon, Othonocheirodus and Rhinopetitia (Lucena, Lucena, 2002; Netto-Ferreira et al., 2014). In D. stigmaturus, the atrophied upper lip exposes the upper maxilla as in B. lethostigmus. Lucena, Lucena (2002) also observed that this character is an independent acquisition on these species. On the other hand Netto-Ferreira et al. (2014) suggested that this character plus the morphological similarity of outer series teeth of the premaxilla were strong evidence towards a relationship among the stevardiines B. lethostigmus, Bryconacidnus, Ceratobranchia, Monotocheirodon, Othonocheirodus, Rhinobrycon and Rhinopetitia. Again, we refute this hypothesis of primary homology due to differences in the origin of the single tooth series and lip reduction during the ontogenetic development of these species. This hypothesis also fails considering the phylogeny based on molecular data presented by Thomaz et al. (2015a), showing Bryconamericus lethostigmus more closely related to other Bryconamericus species than to the genera listed above.

\section{Acknowledgments}

We are grateful to Carlos A. S. Lucena (PUCRS) for material loan, Doug Nelson and Richard P. Vari (in memoriam) for their hospitality during visits at UMMZ and NMNH, respectively. We thank Juliana M. Wingert, Aline Fregonezi and Renata Fagundes for assistance in the molecular biology laboratory at Departamento de Zoologia, UFRGS and Karine $\mathrm{O}$. Bonatto for help in identifying the food items. This work was supported by CNPq (Proc. 160848/2011-3 to AH and 300705/2010-7; 477318/2012-6 to LRM) and by Capes (Proc. 99999.002713/2014-04 to AH).

\section{References}

Abell R, Thieme ML, Revenga C, Bryer M, Kottelat M, Bogutskaya N, Coad B, Mandrak N, Balderas SC, Bussing W, Stiassny MLJ, Skelton P, Allen GR, Unmack P, Naseka A, Ng R, Sindorf N, Robertson J, Armijo E, Higgins JV, Heibel TJ, Wikramanayake E, Olson D, López HL, Reis RE, Lundberg JG, Pérez MHS, Petry P. Freshwater ecoregions of the world: a new map of biogeographic units for freshwater biodiversity conservation. BioScience. 2008; 58(5):403-14. Available from: http://dx.doi.org/10.1641/b580507
Baicere-Silva CM, Ferreira KM, Malabarba LR, Benine RC, Quagio-Grassiotto I. Spermatic characteristics and sperm evolution on the subfamily Stevardiinae (Ostariophysi: Characiformes: Characidae). Neotrop Ichthyol. 2011; 9(2):377-92. Available from: http://dx.doi.org/10.1590/S167962252011005000014

Bandelt HJ, Forster P, Röhl A. Median-joining networks for inferring intraspecific phylogenies. Mol Biol Evol. 1999, Jan; 16(2):37-48.

Bertaco VA, Ferrer J, Carvalho FR, Malabarba LR. Inventory of the freshwater fishes from a densely collected area in South America - a case study of the current knowledge of Neotropical fish diversity. Zootaxa. 2016; 4138(3):401-40. Available from: http://dx.doi.org/10.11646/zootaxa.4138.3.1

Bermingham E, McCafferty SS, Martin AP. Fish biogeography and molecular clocks: perspectives from the Panamanian Isthmus. In: Kocher TD, Stepien CA, editors. Molecular systematics of fishes. San Diego: Academic Press; 1997. p.113-28.

Böhlke JE. Studies on fishes of the fish family Characidae, No. 7: a new genus and species of glandulocaudinae characids from central Brazil. Stanford Ichthyological Bulletin. 1954; 4(4):265-74.

Charcansky A. Estudo comparado da dentição em representantes da ordem Characiformes (Teleostei, Ostariophysi, Othophysi). [MSc Dissertation on the Internet]. Porto Alegre: Pontifícia Universidade Católica do Rio Grande do Sul; 2006. Available from: Repositório Institucional Pontifícia Universidade Católica do Rio Grande do Sul. http://hdl.handle.net/10923/5383

Conselho Estadual do Meio Ambiente (CONSEMA). Resolução Consema No 002. Florianópolis, Santa Catarina: Secretaria de Estado do Desenvolvimento Econômico Sustentável, Conselho Estadual do Meio Ambiente (CONSEMA); 2011 [2011 Dec 06].

Cooke GM, Beheregaray LB. Extremely high variability in the S72 intron of the Amazonian cardinal tetra (Paracheirodon axelrodi) J Fish Biol. 2007, Aug; 71(Suppl.A):132-140. Available from: http://dx.doi.org/10.1111/j.1095-8649.2007.01478.x

Drummond AJ, Ashton B, Buxton S, Cheung M, Cooper A, Duran C, Heled J, Kearse M, Markowitz S, Moir R, Stones-Havas S, Sturrock S, Swidan F, Thierer T, Wilson A. Geneious v5.6. New Zealand: Biomatters; 2012. Available from: http://www. geneious.com

Eigenmann $\mathrm{CH}$. The Cheirodontinae, a subfamily of minute characid fishes of South America. Memoirs of the Museum of Comparative Zoology. 1915; 7(1):1-100.

Excoffier L, Lischer HEL. Arlequin suite ver 3.5: A new series of programs to perform population genetics analyses under Linux and Windows. Mol Ecol Resour. 2010, Mar; 10(3):56467. Available from: http://dx.doi.org/10.1111/j.17550998.2010.02847.x

Fink WL, Weitzman SH. The so-called cheirodontin fishes of Central America with descriptions of two new species (Pisces: Characidae). Washington (DC): Smithsonian Institution Press; 1974. (Smithsonian contributions to Zoology; No. 172).

Fontana CS, Bencke GA, Reis, RE. Livro vermelho da fauna ameaçada de extinção no Rio Grande do Sul. Porto Alegre: Edipucrs; 2003. 
Géry J. Characoids of the world. Neptune City, New Jersey: T. F. H. Publications; 1977.

Gomes AL. A small collection of fishes from Rio Grande do Sul, Brazil. Ann Arbor: University of Michigan Press; 1947. (Miscellaneous Publications, Museum of Zoology, University of Michigan; No. 67).

Giraudoux P. Data analysis in ecology: package 'pgirmess'. Repository CRAN; 2013.

Hall TA. BioEdit: a user-friendly biological sequence alignment editor and analysis program for Windows 95/98/NT. Nucleic Acids Symp Ser. 1999; 41:95-8.

Hammer Ø, Harper DAT, Ryan PD. PAST: Paleontological statistics software package for education and data analysis. Palaeontol Electron. 2001; 4(1):1-9.

Hirschmann A, Thomaz AT, Malabarba LR, Fagundes NJR. Riverine habitat specificity constrains dispersion in a Neotropical fish (Characidae) along Southern Brazilian drainages. Zool Scr. 2015, Feb; 44(4):374-82. Available from: http://dx.doi.org/10.1111/zsc.12106

Javonillo R, Malabarba LR, Weitzman SH, Burns JR. Relationships among major lineages of characid fishes (Teleostei: Ostariophysi: Characiformes), based on molecular sequence data. Mol Phylogenet Evol. 2010; 54(2):498-511. Available from: http://dx.doi.org/10.1016/j.ympev.2009.08.026

Kimura M. A simple method for estimating evolutionary rates of base substitutions through comparative studies of nucleotide sequences. J Mol Evol. 1980, Jun; 16(2):111-20.

Lanfear R, Calcott B, Ho SYW, Guindon S. PartitionFinder: combined selection of partitioning schemes and substitution models for phylogenetic analyses. Mol Biol Evol. 2012; 29(6):1695-1701. Available from: http://dx.doi.org/10.1093/ molbev/mss 020

Li C, Ortí G, Zhang G, Lu G. A practical approach to phylogenomics: the phylogeny of ray-finned fish (Actinopterygii) as a case study. BMC Evol Biol. 2007; 7:44[11p.]. Available from: http://dx.doi.org/10.1186/1471-2148-7-44

Li WLS, Drummond AJ. Model averaging and Bayes factor calculation of relaxed molecular clocks in Bayesian phylogenetics. Mol Biol Evol. 2011, Sep; 29(2):751-61. Available from: http://dx.doi.org/10.1093/molbev/msr232

Librado P, Rozas J. DnaSP v5: A software for comprehensive analysis of DNA polymorphism data. Bioinformatics. 2009; 25(11):1451-52. Available from: http://dx.doi.org/10.1093/ bioinformatics/btp 187

Lucena CAS. Revisão e redefinição do gênero neotropical Charax Scopoli, 1777 com a descrição de quatro espécies novas (Pisces; Characiformes; Characidae). Com Mus Ciênc Tecnol PUCRS. 1987; 40:5-124.

Lucena CAS, Lucena ZMS. Redefinição do gênero Deuterodon Eigenmann, 1907 (Ostariophysi: Characiformes: Characidae). Com Mus Ciênc Tecnol PUCRS. 2002; 15(1): 113-35.

Malabarba LR. Monophyly of the Cheirodontinae, characters and major clades (Ostariophysi: Characidae). In: Malabarba LR, Reis RE, Vari RP, Lucena ZMS, Lucena C AS, editors. Phylogeny and classification of Neotropical fishes. Porto Alegre: Edipucrs; 1998. p.193-233.
Malabarba LR, Isaia EA. The fresh water fish fauna of the rio Tramandaí drainage, Rio Grande do Sul, Brazil, with a discussion of its historical origin. Com Mus Ciênc Tecnol PUCRS. 1992; 5(1):197-223.

Malabarba LR, Neto PC, Bertaco VA, Carvalho TP, Santos JF, Artioli LGS. Guia de identificação dos peixes da bacia do rio Tramandaí. Porto Alegre: Via Sapiens; 2013.

Malabarba LR, Weitzman SH. Description of a new genus with six new species from southern Brazil, Uruguay and Argentina, with a discussion of a putative characid clade (Teleostei: Characiformes: Characidae). Com Mus Ciênc Tecnol PUCRS. 2003; 16(1):67-151.

Marques AAB, Fontana CS, Vélez E, Bencke GA, Schneider M, Reis RE. Lista das Espécies de Fauna Ameaçadas de Extinção no Rio Grande do Sul. Decreto no 41.672 de 11 de junho de 2002. Porto Alegre: FZB/MCT/ PUCRS/PANGEA; 2002.

Medrano JF, Aasen E, Sharrow L. DNA extraction from nucleated red blood cells. Biotechniques. 1990; 8(1):43.

Menezes NA, Weitzman SH, Quagio-Grassiotto I. Two new species and a review of the inseminating freshwater fish genus Monotocheirodon (Characiformes: Characidae) from Peru and Bolivia. Pap Avulsos Zool. 2013; 53(10):129-44. Available from: http://dx.doi.org/10.1590/S0031-10492013001000001

Miller KG, Mountain GS, Wright JD, Browning JV. A 180-millionyear record of sea level and ice volume variations from continental margin and deep-sea isotopic records. Oceanography. 2011; 24(2):40-53. Available from: http://dx.doi.org/10.5670/ oceanog.2011.26

Mirande JM. Phylogeny of the family Characidae (Teleostei: Characiformes): from characters to taxonomy. Neotrop Ichthyol. 2010; 8(3):385-568. Available from: http://dx.doi.org/10.1590/ S1679-62252010000300001

Ministério do Meio Ambiente (MMA). Lista Nacional das Espécies da fauna brasileira ameaçadas de extinção. 2014. Available from: http://www.icmbio.gov.br/portal/biodiversidade/fauna-Brasileira /60-fauna-brasileira/2741-Lista-de-Espécies Ameaçadas-saibamais.html

Nabholz B, Glémin S, Galtier N. Strong variations of mitochondrial mutation rate across mammals - the longevity hypothesis. Mol Biol Evol. 2008; 25(1):120-30. Available from: http://dx.doi. org $/ 10.1093 / \mathrm{molbev} / \mathrm{msm} 248$

Nabholz B, Glémin S, Galtier N. The erratic mitochondrial clock: variations of mutation rate, not population size, affect mtDNA diversity across birds and mammals. BMC Evol Biol. 2009; 9(1):54 [13p.]. Available from: http://dx.doi.org/10.1186/14712148-9-54

Netto-Ferreira AL, Birindelli JLO, de Sousa LM, Mariguela TC, Oliveira C. A new miniature characid (Ostariophysi: Characiformes: Characidae), with phylogenetic position inferred from morphological and molecular data. PLoS ONE. 2013; 8:e52098 [7p.]. Available from: http://dx.doi.org/10.1371/ journal.pone.0052098

Netto-Ferreira AL, Birindelli JLO, Sousa LM, Menezes NA. A new species of Rhinopetitia Géry 1964 (Ostariophysi: Characiformes: Characidae) from the rio Teles Pires, rio Tapajós basin, Brazil. J Fish Biol. 2014; 84(5):1539-50. Available from: http://dx.doi. org/10.1111/jfb.12384 
Oliveira C, Avelino GS, Abe KT, Mariguela TC, Benine RC, Ortí G, Vari RP, Castro RMC. Phylogenetic relationships within the speciose family Characidae (Teleostei: Ostariophysi: Characiformes) based on multilocus analysis and extensive ingroup sampling. BMC Evol Biol. 2011; 11:275 [25p.]. Available from: http://dx.doi.org/10.1186/1471-2148-11-275

Ornelas-García CP, Domínguez-Domínguez O, Doadrio I. Evolutionary history of the fish genus Astyanax Baird \& Girard (1854) (Actinopterygii, Characidae) in Mesoamerica reveals multiple morphological homoplasies. BMC Evol Biol. 2008; 8:340[17p.]. Available from: http://dx.doi.org/10.1186/14712148-8-340

de Pinna MCC. Concepts and tests of homology in the cladistic paradigm. Cladistics. 1991; 7(4):367-94.

$\mathrm{R}$ Development Core Team. R: a language and environment for statistical computing [Computer software manual - Internet]. Vienna: R Foundation for Statistical Computing; 2013. Available from: https://www.rproject.org/

Rambaut A, Drummond AJ. Tracer v1.5. 2009. Available from: http://beast.bio.ed.ac.uk/Tracer

Reeves RGUY, Bermingham E. Colonization, population expansion, and lineage turnover: phylogeography of Mesoamerican characiform fish. Biol J Linn Soc. 2006; 88(2):235-55. Available from: http://dx.doi.org/10.1111/ j.1095-8312.2006.00619.x

Reis RE, Lucena ZMS, Lucena CAS, Malabarba LR. Peixes. In: Fontana CS, Bencke GA, Reis RE, editors. Livro vermelho da fauna ameaçada de extinção no Rio Grande do Sul. Porto Alegre: Edipucrs; 2003. p.117-46.

Ribeiro AC. Tectonic history and the biogeography of the freshwater fishes from the coastal drainages of eastern Brazil: an example of faunal evolution associated with a divergent continental margin. Neotrop Ichthyol. 2006; 4(2):225-46. Available from: http://dx.doi.org/10.1590/S1679-62252006000200009

Rio Grande do Sul. Decreto N. ${ }^{\circ}$ 51.797. Porto Alegre: DOE n. ${ }^{\circ}$ 173; 2014 [2014 Sep 09].

Tamura K, Stecher G, Peterson D, Filipski A, Kumar S. MEGA6: Molecular Evolutionary Genetics Analysis (MEGA) software version 6.0. Mol Biol Evol. 2013; 30(12):2725-29. Available from: http://www.megasoftware.net

Taylor WR, Van Dyke GC. Revised procedures for staining and clearing small fishes and other vertebrates for bone and cartilage. Cybium. 1985; 9(2):107-19.

Thomaz AT, Arcila D, Ortí G, Malabarba LR. Molecular phylogeny of the subfamily Stevardiinae Gill, 1858 (Characiformes: Characidae): classification and the evolution of reproductive traits. BMC Evol Biol. 2015a; 15:146 [25p.]. Available from: http://dx.doi.org/10.1186/s12862-015-0403-4
Thomaz AT, Malabarba LR, Bonatto SL, Knowles LL. Testing the effect of palaeodrainages versus habitat stability on genetic divergence in riverine systems: study of a Neotropical fish of the Brazilian coastal Atlantic Forest. J Biogeogr. 2015b; 42(12):2389-2401. Available from: http://dx.doi.org/10.1111/ jbi.12597

Thompson JD, Higgins DG, Gibson TJ. CLUSTAL W: improving the sensitivity of progressive multiple sequence alignment through sequence weighting, position specific gap penalties and weight matrix choice. Nucleic Acids Res. 1994; 22(22):467380 .

Tringali MD, Bert TM, Seyoum S, Bermingham E, Bartolacci D. Molecular phylogenetics and ecological diversification of the transisthmian fish genus Centropomus (Perciformes: Centropomidae). Mol Phylogenet Evol. 1999; 13(1):193-207. Available from: http://dx.doi.org/10.1006/mpev.1999.0624

Vogel C. Estratégias de história de vida de peixes neotropicais em diferentes tipos de habitat. [MSc Dissertation on the Internet]. Porto Alegre: Universidade Federal do Rio Grande do Sul; 2012. Available from: Repositório Digital Universidade Federal do Rio Grande do Sul. http://hdl.handle.net/10183/60554

Weitzman SH, Fink WL. Relationships of the neon tetras, a group of South American freshwater fishes (Teleostei, Characidae) with comments on the phylogeny of new world Characiforms. Bull Mus Comp Zool. 1983; 150(6):339-95.

Weitzman SH, Fink SV. Xenurobryconin phylogeny and putative pheromone pumps in glandulocaudine fishes (Teleostei: Characidae). Washington (DC): Smithsonian Institution Press; 1985. (Smithsonian contributions to Zoology; No. 421).

Weitzman SH, Palmer L. A new species of Hyphessobrycon (Teleostei: Characidae) from the Neblina region of Venezuela and Brazil, with comments on the putativerosy tetra clade. Ichthyol Explor Freshw. 1997; 7(3/4):209-42.

Zelditch ML, Fink WL. Heterochrony and heterotopy: stability and innovation in the evolution of form. Paleobiology. 1996; 22(2): 241-54. 